\title{
Big Fish, Small Pond: \\ The Effect of Rank at Entry on Post-Secondary Outcomes
}

\author{
A. Abigail Payne ${ }^{1}$ \\ Justin Smith ${ }^{2}$ \\ Running Head: Big Fish, Small Pond \\ ${ }^{1}$ Melbourne Institute: Applied Economic \& Social Research \\ University of Melbourne \\ Level 5, FBE Building \\ 111 Barry Street \\ Carlton, Victoria 3010 \\ Australia \\ abigail.payne@unimelb.edu.au \\ ${ }^{2}$ Department of Economics \\ Lazaridis School of Business and Economics \\ Wilfrid Laurier University \\ 75 University Ave. W. \\ Waterloo, Ontario N2L3C5 \\ Canada \\ jusmith@wlu.ca \\ corresponding author
}

JEL Codes: I2, I23

Acknowledgement Footnote: We thank participants of the Waterloo Laurier Labor (WALL)

seminar, CES-ifo Economics of Education Network, Association for Education Finance and

Policy Annual Conference, International Institute for Public Finance Conference, and Canadian

Economic Association, and Elizabeth Dhuey for valuable comments. We thank the providers of

This is the author manuscript accepted for publication and has undergone full peer review but has not been through the copyediting, typesetting, pagination and proofreading process, which may lead to differences between this version and the Version of Record. Please cite this article as doi: $10.1002 /$ soej.12420

This article is protected by copyright. All rights reserved. 
the data (four Ontario universities), Ontario University Application Centre, as well as the Public Economics Data Analysis Laboratory. Funding for this research has been provided through SSHRC Insight Grants.

Abstract:. We study whether a student's rank in her program of study in university affects short and longer term educational outcomes. Using student-level administrative data from four universities across many cohorts, we show that ranking higher compared to students in the same program in the same year has a positive effect on grade point average and lowers the probability of switching programs at the end of the first year, but has small effects on credit completion, departures, and degree attainment. Our results suggest that being the big fish in the small pond produces moderate advantages in higher education. 


\section{Introduction}

In his recent book "David and Goliath: Underdogs, Misfits, and the Art of Battling Giants,” Malcolm Gladwell tells the story of Caroline Sacks, a high-achieving high school graduate applying for postsecondary studies in science. She narrows her choices to Brown University and the University of Maryland as a backup, ultimately choosing Brown due in part to its prestige. Not long into the program, she finds herself struggling relative to her classmates and ultimately drops out. The insinuation in the book is that her misfortune is caused in part by her position in the ability distribution at Brown: despite being high in the overall distribution of ability, she is low in the distribution at Brown because only the highest achievers in the population study there. When asked what might have happened had she attended Maryland, she surmises that she would still be in a science program, presumably because she would rank much higher. Gladwell suggests that this anecdote is one example of a broader pattern where students of equivalent ability fare worse at more selective institutions because they rank lower.

Why might postsecondary outcomes like degree completion improve when a student is ranked higher? Gladwell suggests the relationship is driven by the Big Fish Little Pond Effect (BFLPE), a theory proposed by Marsh and Parker (1984) that posits one’s position amongst one's peers can affect self-perceived ability, which ultimately affects academic performance. It could also be that top ranked students get disproportionate attention from instructors, which would boost their performance, or that universities grade students on a curve, and being ranked higher means higher grades and a greater likelihood of completing a degree program. 
Despite the potential importance of rank when choosing among postsecondary institutions, there is relatively little quantitative analysis on how one's position in a program affects outcomes in higher education; the bulk of the research is focused on students at the elementary and secondary levels. We study the effect of rank at entry into postsecondary on achievement and persistence using administrative records that capture $10+$ cohorts of students across four programs (arts, science, business, and engineering) in four universities of varying reputations/perceived quality. With this unique data set we observe high school grades, the high school grade point average (GPA) used for admission, and the following outcomes for students in these cohorts: university GPA after the first year of study, credits completed after the first year of study, staying in the university after the first year of study, staying in a program after the first year of study, and completing a degree at the university within six years of entering university. Using a clean identification strategy that leverages the random variation in the rank of students who have the same high school GPA at the time they enter a program at a university, we test whether the position within one's cohort affects her performance and/or decisions to stay in a given degree program and to receive a university degree.

The results suggest, on average, modest effects of rank on university GPA and staying registered in a given program of study. We also find evidence of a small rank effect on credits completed, staying in university, and degree completion. Looking across the distribution of students, however, we observe interesting differences in the tails. Moving up one decile in rank increases university GPA by roughly 0.16 standard deviations for those in the bottom 10 percent, 
and 0.28 standard deviations for those at the top 10 percent. We also find that those ranked at the bottom and top 10 percent are 2.6 percentage points more likely to stay in their program when ranked once decile higher. Finally, a decile increase in rank increases the likelihood of finishing a degree within six years by roughly 2 percentage point for those in the bottom 10 percent, and 1 percentage point for those in the top 10 percent. We also observe in some cases differences in the effect of rank on across gender and across program of study.

Section 2 provides a brief literature review and empirical framework. Section 3 outlines the Canadian postsecondary sector. Section 4 describes our data set and Section 5 reports our results. We conclude in Section 6.

\section{Literature Review}

The Big Fish Little Pond Effect is a theory proposed by Marsh and Parker (1984) that has a long history in the psychology literature. Its basic hypothesis is that students develop beliefs about their own cognitive and/or non-cognitive ability called the Academic Self Concept (ASC), and these beliefs are negatively correlated with the average ability of a comparison group. This implies, for instance, that a student ranked lower in the ability distribution at their school will have a lower ASC. Having a low ASC is important because it can result in such things as low motivation and/or academic interest which can affect course selection, achievement and social or economic well-being (Marsh et. al., 2008). In line with the theory, an extensive set of results over the past 30 years shows that rank is positively related with ASC and with performance on 
academic outcomes at the grade school level, the high school level, and that these effects can be long-lasting. ${ }^{1}$ Despite the consistency of the results, the exact mechanisms underlying BFLPE are not fully understood. See, e.g. Dai and Rinn (2008). ${ }^{2}$

Capturing the BLFPE on academic outcomes is challenging econometrically. An ideal experiment would be one where a student is observed in two different environments: one where she is ranked high and one where she is ranked low relative to her cohort. In such an experiment we could test whether the student's outcomes differ between these environments. Obviously, this is an impossible experiment to undertake. More feasible identification strategies involve constructing groups of students with similar characteristics but who rank differently to compared to each other. Much of the psychology literature focuses on the variation observed in ranks of students of similar ability across schools that have different average abilities. Unless the schools are identical in key features, comparing outcomes between schools will result in a BFLPE that is biased by differences in student background characteristics, possibly due to selection bias if students have some control over the school she attends and/or schools can select students into a school.

A within school analysis focuses instead on exploiting the relative position of students in different cohorts at the same school across time. This estimation strategy is used in a series of recent studies of the effect of rank on outcomes for postsecondary, secondary, and elementary school students. Elsner, Isphording, and Zölitz (2019) - the most closely related study to ours finds that within course section rank at a Dutch business school has modest positive effects on 
passing the course, achievement, and taking further math electives. Interestingly, the effects of rank on those outcomes and several others are much stronger when ranking is done within gender rather than pooling men and women. Other studies focus on ranking in elementary and secondary school. Denning, Murphy, and Weinhardt (2018) find that a higher $3^{\text {rd }}$ grade rank has several positive short and long term impacts, including better test scores, higher likelihood of graduating high school and enrolling in college, and better earnings. Murphy and Weinhardt (2018) rank students based on their performance on a standardized test in elementary school and study the effect of this rank on performance on secondary school standardized tests at ages 14 and 16. Their results suggest that, after controlling for ability, students with higher ranks receive high test scores relative to students with lower ranks. Finally, a similar study by Elsner and Isphording (2017) finds that rank based on performance in the years leading up to high school attendance results in positive longer-term effects on measures such as high school completion, post-secondary attendance, and post-secondary completion. ${ }^{3}$

Our study fits into the existing literature by studying outcomes in university based on the ranking of students in their cohort within a broad disciplinary program (e.g. engineering, science) within a university. The measurement of rank, which is discussed in more detail below, is based on measures of high school performance used by the university for admission. By focusing on the within program/within university rank, we are exploiting the fact that a student with similar admission criteria will have a different rank based on the admission criteria of the peers in her cohort. Our study differs from Elsner, Isphording, and Zölitz (2019) along several dimensions. 
First, we rank based on high school GPA used for university admissions rather than prior university GPA. Second, we rank among a broader peer group. Finally, we focus on a larger set of universities and programs. As we note below, this leads to several differences in the results.

Also relevant to our paper is the literature on peer effects in education. Many researchers have studied whether features of a student's social group - average achievement, or background characteristics - affect their outcomes and how various programs are influenced through peers. Based on the review by Sacerdote (2011), the findings suggest that, at the elementary and secondary school levels, increases in peer achievement have a positive effects on test scores, and in particular adding high ability peers to a classroom has large effect on students at the top end of the distribution. Increases in the share of the class that is female also has positive effects on achievement, which operates partly through increasing the average achievement of the class, and partly through other channels. At the postsecondary level, studies of randomly-assigned roommates indicate moderate positive effects of peer achievement on own achievement. Finally, peers are show to have strong effects on non-academic outcomes like alcohol and drug consumption.

Our estimate of the rank effect is very similar to, but distinct from, a peer effect. The estimator isolates the effect of a student's position in the distribution on their eventual performance. The variation in student ranking comes from changes in the average achievement of the rest of the cohort. Using this source of variation, any measured effect could be interpreted as a peer effect because it is driven by changes in the ability of others in the class. An alternative 
specification would be to hold constant the average ability of other students and utilize variation that is drawn from changes in the shape of the distribution. We show below that we get similar estimates using both types of estimation strategies.

To the extent that one interprets the rank effect as a peer effect, it is important to highlight that, unlike some existing peer effects work, our estimates are not subject to the reflection problem (Manski, 1993). This feedback between individual and peer outcomes leads to biased estimates of peer effects. Our empirical approach ranks students at the time they enter post-secondary education using their predetermined high school grade point average. The outcomes under study all occur at later points in time. It is therefore not possible for a feedback from individual outcomes to rank, and so the reflection problem does not apply.

\section{Post-Secondary Education in Ontario}

Education is a provincial responsibility in Canada, and because our data consists entirely of Ontario students, we will outline the most important aspects of postsecondary schooling in that province. The postsecondary sector is separated into two broad groups: universities and colleges. Universities are academic institutions. They all offer 3 or 4 year undergraduate degrees, and most also offer graduate and professional programs at both the masters and doctoral levels. Colleges, on the other hand, are geared more towards technical training. They mostly offer diploma and post-degree certificate programs, though in more recent years some of the colleges have introduced a bachelor's degree. Currently there are 24 public universities and 24 public 
colleges operating in Ontario that serve the vast majority of postsecondary students. There are also a few small private universities that have a religious focus. In the 2016/2017 academic year, there were 527,463 students enrolled in universities in Ontario, and 285,891 in colleges (Statistics Canada, 2019).

Focusing on the university sector, there is wide variation in terms of size, specialization, and prestige. Maclean’s magazine, which annually ranks universities in Canada, separates schools into three groups: Medical/doctoral, comprehensive, and primarily undergraduate. The medical/doctoral schools tend to be large, research-focused institutions that offer a wide range of graduate programs, including medical and doctoral programs as the name suggests. Examples of such schools are the University of Toronto, McMaster University, and Queen’s University. Comprehensive institutions are also research-focused and offer both undergraduate and graduate programs, but not to the same degree as the medical/doctoral schools. Examples are University of Waterloo, York University, and Carleton University. Finally, primarily undergraduate universities are smaller and focus on undergraduate students, though may still offer some graduate programs. Examples are Trent, Lakehead, and Brock Universities. While institutions that rank highly in their category in the MacLean’s rankings are typically viewed as better overall, prestige is attached more to programs within universities. For example, the University of Waterloo has a very prestigious Engineering program, while Western University has a prestigious business program. ${ }^{4}$ 
The postsecondary application process is unique in that students do not apply directly to a university, but rather through a central application hub called the Ontario Universities Application Centre (OUAC) that acts as an intermediary between students and universities. Students pay a nominal fixed fee that covers the submission of up to three applications. Applications to additional programs incur an additional fee. It is worth noting that, unlike the United States, students in Ontario apply directly to programs at universities;each program application counts as a single application. Applications are due in January, and students receive offers or refusals from universities prior to the end of May. ${ }^{5}$

At the university level, the admission process is fairly standardized across institutions. With their application, all students submit their "best six" course average based on a set of provincially designated courses that are identified as eligible for use in university admissions. This average is the main measure upon which admission decisions are made. For some programs, a university program may identify one or more high school courses that must be used to compute the "best six" average.. For example, in the Bachelor of Business Administration (BBA) program at Wilfrid Laurier University the average must include the grades for one of a set of English courses, a functions course, and either calculus or data management. Specialized programs will typically base admissions decisions on more than grades. For example, in music programs an audition is required.

\section{Data and Key Variables}

\section{Data Description}


Our data come from two main sources. The first is the administrative student-level records from four Ontario Universities on "101” students - direct applicants from Ontario high schools registered between 1994-2005. These 101 students account for roughly $90 \%$ of all students entering Ontario universities (Dooley, Payne and Robb, 2011). ${ }^{6}$ The names of the schools are masked for privacy reasons, so we instead refer to them as Universities A, B, C, and D. We have detailed information for each student about degree program enrolled, grade point average, degrees conferred, credits completed or failed, scholarships, and a small list of demographic characteristics. This information allows us to study each student’s academic achievement, progression, and graduation at each stage while they are registered at the university. Unfortunately, the data do not track students who leave the four schools in our sample.

Though we have detailed information about each student's precise degree program, in practice we regroup these programs into broad categories, and study only those classified as applying to programs in Arts, Business, Engineering, and Science. ${ }^{7}$ The key reason for this regrouping is that it is infeasible to keep track of the vast number of different degree programs at each university, but we also regroup because it is not crucial to the analysis to have such detailed program information. All four universities offer Arts and Science programs; University A does not have an engineering program, and University C does not have a business program. ${ }^{8}$

We merge the university administrative records to application data from the Ontario Universities Application Centre (OUAC) on 101 students over the same period. We have information on the entire list of Ontario schools and programs to which 101 students apply, an 
encrypted high school identifier, high school grades, mother tongue, gender, birth month and year, marital status, country of residence, and the dissemination area where they live. ${ }^{9}$

Finally, we link a host of Census information to student records through their dissemination area. We attach data from the Census period (which runs every five years) most relevant to the location of the student during high school. The measures captured by the Census include education levels of adults residing in the neighbourhood, household income, and family structure. Appendix Table A1 reports the average statistics of the measures that captures information about the students studied as well as the neighbourhood characteristics.

\section{Analysis Sample}

The sample universe consists of all 101 students who enter an Arts, Business, Engineering, or Science program in one of the four universities as full-time students in September between 1994 and 2005. To focus attention on standard post-secondary students, we further restrict the sample to students who are between 15 and 20 years old, and who attempt between 4 and 10 credits (8 to 20 one-semester classes) in their first year. Not all universities have provided data in every year across this timespan: University A is observed from 1994 to 2005, University B from 1994 to 2004, University C from 1994 to 2004, and University D from 1999 to 2005. This amounts to 114,713 student observations over this period.

From this universe, we exclude 96 students $(<1 \%)$ with no match with Census data; 11 students $(<1 \%)$ who have an entry average below $50 \%$ or a missing entry average; 344 students 
$(<1 \%)$ who have missing values for controls. After these exclusions, we are left with an analysis sample of 114,262 students. ${ }^{10}$

\section{Outcomes}

Our primary outcome measure is student university GPA at the end of year 1 of their academic program. The university GPA is a score than ranges from 0 to 12 that represents the average achievement (credit-weighted) over all courses taken in the first year of university. We use a 12-point scale instead of the typical 4 point scale common in US universities because two of the four universities studied use a 12 point scale and it was straightforward to convert the other two universities to it. For reference, Appendix Table A3 reports a mapping between this grade point scale and other types of marking schemes (percentage 0-100, 12 point scale, 4 point scale). Note that for the regressions, we standardize this variable to be mean zero, standard deviation 1 within each university/program/cohort.

\section{Table 1 approximately here}

Table 1 reports the summary statistics for university GPA stratified by university and entry program. Across the sample of four universities, the average GPA is 6.88 with a standard deviation of 2.6. The overall GPA for universities A and C are higher than the overall GPAs for universities B and D. Within each university, the distribution of GPAs varies across the programs. For example, business students receive higher marks than arts and science students at university A, while science students receive higher marks at universities B and D than students in the other three programs. 


\section{Table 2 approximately here}

While our analysis primarily focuses on university GPA, we also developed four other

outcome measures. The average values for these measures are reported in Table 2 .

- Total Credits Earned in Year 1: A credit has been normalized to 0.5 for each onesemester course. Under this metric, a full-time student is expected to take a minimum of 5 credits per year, or 10 one-semester courses. Note that in engineering, a student often takes more than 10 one-semester courses in a year. Across all universities and programs, the average student is observed with slightly less than 5 credits. In our sample, about $7 \%$ of students take less than 4 credits, 23\% take less than 5 credits, $26 \%$ take more than 5 credits, and $4 \%$ take more than 6 .

- Observed Enrolling and Earning Credits in Year 2: This measure captures staying at the university beyond the first year. As previous research has suggested that degree completion is strongly positively correlated with returning for the second year of university, this measure is capturing the extent to which there may be a BFLPE on staying at a university. If a student leaves the university, that student may drop out of university all together and/or transfer to another university. The value of this measure is an indicator variable equal to 0 or 1 . As Table 1 suggests, roughly $94 \%$ of students enroll in year 2, where the retention rate is highest at University D.

- Observed in the Same Program in Year 2: This measure captures persistence in the choice of university program. Unlike many US institutions where a student enrolls first in the university and then declares her program (major) during the first few years of schooling, Canadian universities follow many other commonwealth and European countries in expecting a student to declare her program at the outset. While a student will have opportunities to switch programs within a university, typically the pattern for those who switch is to switch from a more to less demanding program. The value of this measure is an indicator variable equal to 0 or 1 . For students who are not observed enrolling and earning credits in year 2 we assign a value of $0 .{ }^{11}$ The means of this measure is approximately 0.10 less than that observed for the measure that captures staying at the university for year 2 .

- Degree Completion within 6 Years: Graduation within six years is in indicator for obtaining any degree within six years of first enrolling at the university. We allow six years because at least one of the universities in our sample has a co-op program, which may take six years for some on-time students to complete. This too is an indicator variable equal to 0 or 1 . Across all programs and university the mean value is relatively high, greater than 0.75 . Not too surprisingly there is a strongly positive correlation between the share of students who return for a second year and the share 
observed graduating. Of those who are not observed graduating within 6 years, approximately 33\% did not return to the university in year 2 .

\section{Ranking}

We construct a student's rank based on her average in the top six high school courses which would be used for admission purposes, which we call the high school GPA (HS GPA). ${ }^{12}$ Our rank measure is created by grouping the students by their enrolled program, university, and cohort. After standardizing HS GPA (discussed below), students are then assigned their quantile in the distribution of this variable, a value between 0 and 1 with 1 representing being at the top of one's cohort/program/university. This rank value organizes the students relative to others in the same program, university, and year. Because this is an entry cohort in a university program, these students take similar classes and interact with each other, meaning this is at least one likely peer group with which individuals compare themselves academically.

While the measure we use to rank students is different from other papers in the literature, which mainly rank people on standardized test scores, there are several reasons why it is a good one in our context. First, as explained in section III, the top six is the primary measure that all universities use for admission, and for the vast majority of programs it is the only measure used to decide admission. This means that university admission officials actively compare and contrast students directly on this measure. Also, information of likely cutoff points for admission by university and program is published and known by the students. Second, performing well in university is not simply a matter of brain power, but rather a combination of things such as good organizational skills, study time, attending tutorials, working in groups, etc. 
In support of this idea, there is an extensive literature that compares the predictive power of high school GPA to the SAT for college success shows that both are significant predictors, and that the high school GPA does at least as well as the SAT (Betts and Morrell 1999; Camara and Echternacht 2000; Cohn et al. 2004). Based on that finding, for the purpose of capturing a BFLPE for university students, we believe the best measure is one that captures a combination of both cognitive and noncognitive ability. The literature shows that high school GPA is correlated with both cognitive ability and a host of non-cognitive factors like parent income and education, high school quality, gender, race, and motivation (Rothstein 2004; Zwick and Green 2007). While our HS GPA measure is based on six courses and so is not exactly equivalent to a full high school GPA, it is very similar and should capture both cognitive and non-cognitive factors in the same manner.

There are, however, potential issues with ranking students this way. One is that grading standards may differ across high schools and/or time. Ontario public high schools all operate on the same curriculum, which outlines a common set of expectations for students in different subject areas. So, while we acknowledge that individual teachers may grade differently, they are all anchored by a common and specific set of objectives that limits how much discrepancy there can be between high schools in assessing students. Nevertheless, we take steps to ensure that variation across schools and time does not impact out results. To correct for grade inflation, we standardize high school GPA by subtracting the mean across all university applicants (not just the four universities) and dividing by the standard deviation in each cohort. ${ }^{13}$ In Appendix Table 
A4 we test the robustness of our results to also removing the school mean from HS GPA before ranking students, and show that the effect of rank on outcomes is very similar to the main estimates. ${ }^{14}$ Finally, to demonstrate that across-school variation in grading standards is not that important empirically, we show in Table A5 that in a model where we predict university-level outcomes using the best six average, including school fixed effects does not change the coefficient on the best six average.

A final issue is that from one student to the next, the HS GPA is based on the top six courses. Thus, students will vary in the courses used to construct the HS GPA. For instance, weaker students may take easier courses to boost their average, while strong students take harder courses. There are several reasons to think this is not a major issue in our context. First, weaker students taking easier courses than stronger students would certainly compress the distribution of HS GPA, but it is not clear that it would affect rankings, especially outside the very middle of the distribution. Second, we rank students in the same program and cohort, who are more likely to have similar courses than students in different programs as each program will have one or more core high school courses needed to enter the program. This is especially the case in programs like engineering which usually have a rigid set of courses that students must take as prerequisites. Finally, in Table A6 we show that with few exceptions, a rank based on HS GPA within a university/program/cohort is strongly positively correlated with a ranking based on individual courses English, calculus, data management, chemistry, physics, and biology. For these reasons, we do not think course variation within the HS GPA is a major concern, but to the 
extent that it might be, one could view our results through the lens of measurement error, which would imply some attenuation in our results.

\section{Analysis}

\section{Identification}

Our goal is to measure the independent relationship between a student's rank upon entry into postsecondary and their later educational outcomes. The baseline model we use in our statistical analysis is:

$$
y_{i}=\alpha_{0}+\alpha_{1} \operatorname{rank}_{i}+\sum_{j=1}^{20} \beta_{j} h s g p a_{i}^{v j}+\theta_{1} x_{i}+\theta_{2} z_{n(i)}+\delta_{p s(i)}+\mu_{t}+\varepsilon_{i}
$$

The variable $y_{i}$ the outcome variable capturing performance and decisions made in university (university GPA, credits completed, staying in program/university after year 1, or degree completion within six years). The key explanatory variable is $\operatorname{rank}_{i}$, which as described above is a student's quantile in the HS GPA distribution among others in an academic program at a university in the same year. An important part of identifying the rank effect is to control for each student's ability, so that we are comparing two equivalent students who differ in their position in the distribution. To this end, we control for high school GPA flexibly by breaking it into 20 quantiles $\left(h \operatorname{spp} a_{i}^{v 1}-h s g p a_{i}^{v 20}\right)$ and include a dummy variable for each. The variables $x_{i}$ and $z_{n(i)}$ are individual and neighbourhood Census controls, such as identifiers for female, immigrant, and mother tongue being English, in addition to neighbourhood income, family structure, education, unemployment, ethnicity, and age controls. ${ }^{15}$ The controls also include university/program/cohort averages of each of these variables. Finally, the $\delta_{p s(i)}$ are program by 
university fixed effects and $\mu_{t}$ are year effects. These control for any fixed differences across programs within and across schools, in addition to any common time trends.

This identification strategy is one that is based on there being students with the same high school GPA that are ranked differently based on the year of entry. This variation is illustrated in Figure 1, where we depict the distribution of HS GPAs of students along the x-axis and the values of the rank measures along the y-axis for all university/program combinations. The key variation we use in our estimates is the vertical distance between the distributions holding the high school GPA fixed. In most programs/universities, the largest differences in rank over time happen in the middle of the distribution, for students who have roughly average high school GPAs. In some cases the variation is substantial: in University D Engineering, a student with an entry average slightly above zero is at the median in 2000 , but closer to the $20^{\text {th }}$ percentile in 2003. Similar large differences are observed in other program/university combinations, suggesting that there is sufficient variation in rank to use this particular identification strategy.

\section{Figure 1 approximately here}

The identifying assumption underlying equation 1 is that there are no other unobserved factors that vary within university programs over time that are correlated with rank and also affect our outcomes. Equivalently, all confounding factors are either absorbed by the controls, or are constant within programs and schools. One potential threat comes from varying demographic characteristics of entry cohorts over time. We noted above that the variation in rank comes from differences over time in the average HS GPA of entry cohorts into the same university program. 
If the HS GPA is changing across entry cohorts, average demographic factors might also change, and if they correlate with rank and outcomes it could cause bias. The identification strategy is similar in spirit to the Hoxby (2000a) study of class size on achievement, and the Hoxby (2000b) study of gender and race peer effects on achievement: the rank effects are identified if variation in average achievement (which drives the variation in rank) is random across cohorts within university programs. The main threat to the strategy occurs where the year to year variation in other factors that affect our outcomes is correlated.

As a robustness check, we estimate a more demanding specification where we replace $\delta_{p s(i)}$ and $\mu_{t}$ with a university by program by year effect. This alternative fixed effect controls for constant differences across universities, programs, and time, including changes in the average characteristics of each entry cohort. Thus, the potentially confounding average demographic factors discussed above are fully controlled in this specification. In this more demanding specification, what generates the variation in rank for two students with the same high school GPA is slightly more complicated. One might expect that deviations of high school GPA from its university/program/year mean are perfectly collinear with deviations in rank from its university/program/year mean. That is, being one standard deviation above your entry cohort's average leads to the same departure in rank away from its mean in all cohorts. This is, however, not the case because there are differences in the shape of the high school GPA distribution across programs, universities and time. Two students with an $80 \%$ high school GPA in entry cohorts with the same mean can still have different percentile ranks if, for example, the variance or 
skewness of the distributions is different. It is these differences that allow us to identify the effect of rank despite estimating effects within university, program, and year. This method is also used in both Murphy and Weinhardt (2018) and Elsner and Isphording (2017). As discussed above, a key feature of this specification is that the rank coefficient is not interpreted as a peer effect, because average peer characteristics are held constant. Instead, it is the independent effect of a student's position in the distribution.

As noted above, rank effects are identified by higher-order moments in the high school GPA distribution across university/program/cohort groups. While we believe this goes a long way towards identifying rank effects, we acknowledge that distributional differences across groups may have their own independent effects on outcomes. For instance, professors may teach higher-variance groups differently, which might be a threat to identification.

Relationship between Outcome Measures and Rank

We summarize the relationships between each of our outcomes and rank at entry graphically in Figures 2-6. Before plotting these figures, we first normalized all outcomes and rank by regressing each on HS GPA, university by program fixed effects, and year fixed effects, then taking the residual. Each graph plots the mean of one normalized outcome at each decile of the normalized rank separately by program. The purpose of this exercise is to visualize the independent relationship between the outcomes and rank, net of those three factors.

Figure 2 approximately here 
Figure 2 shows the relationship between GPA and rank at entry. Across all programs, the line is relatively flat when rank is low, but then tilts upward as rank rises above the $60^{\text {th }}$ percentile. For persistence in program plotted in Figure 3, there is a slight positive relationship with rank among business students, but no relationship between the two in all other programs. Figures 4, 5, and 6 show a no relationship between rank for credit completion, persistence in university, and degree completion.

Figure 3, 4, 5, 6 approximately here

Results

Table 3 presents the main estimates of the effect of rank on our first outcome measure: university GPA at the end of year 1. Moving from columns 1 to 4 , we add subsets of control variables to the equation, with column 4 containing the estimates from equation 1 - our preferred specification. In this and all subsequent Tables, the rank variable is scaled such that the coefficient measures the effect of increasing rank by 10 points. ${ }^{16}$ Furthermore, the university GPA variable is scaled to be mean zero, standard deviation 1 within each university/program/year, so coefficients measure the change in standard deviation units from increasing rank. Column 1 shows that in a specification with no controls, ranking higher by one decile increases university GPA by 0.2 standard deviations. The results in column 2 show that adding a flexible control for high school GPA reduces that coefficient only slightly. As we add controls across columns 3 and 4 , the main coefficient falls to roughly 0.1 standard deviations.

Table 3 approximately here 
Columns 4 and 5 of Table 3 explore the results from the more demanding specification that includes universityXprogramXyear fixed effects, which holds constant differences in the average cohort characteristics across all universities and programs and years, and therefore identifies the rank effect using higher order moments of the distribution. The coefficient on rank is slightly lower, but very close to our preferred specification, suggesting that unobserved average cohort characteristics do not play a significant role in determining rank and postsecondary outcomes. We note, however, the possibility that higher order moments of the demographic distribution might correlate with both rank and outcomes.

\section{Figure 7 approximately here}

Figure 7 depicts the results when we focus on various subgroups of students. These results are the marginal effects from an alternative specification where we alter equation 1 to include a cubic in rank with dummies for entry program, and dummies for gender. ${ }^{17}$ Starting first with the nonlinear effects of rank, a change in rank for students second quarter of the distribution (e.g. $25^{\text {th }}$ and $50^{\text {th }}$ percentiles) has a negligible effect on their year 1 university GPA. Rank matters most for those students at the bottom and top ends of the distribution: the marginal effect of rank university GPA is roughly 0.175 for students at the $10^{\text {th }}$ percentile and $75^{\text {th }}$ percentiles, and 0.28 for students at the $90^{\text {th }}$ percentile. Next, we measure the effect of rank on university GPA based on program of study, and find no statistically or economically meaningful differences . Finally, we separated our analysis based on gender. On average, there is a 0.07 difference between men and women, a relatively trivial gap that is not statistically significant. 


\section{Table 4 approximately here}

In Table 4, we report the results for our four additional outcome measures: the number of credit completions at the end of year 1 ; registering in courses at the university in the second year of study; remaining in the program of study in the second year of study; receiving a degree from the same university within six years. For each outcome, we report the results using two specifications: one that includes the university*program fixed effects, year fixed effects, and student/neighbourhood/schooling controls; and one that includes the university*program*year fixed effects and the student/neighbourhood/schooling controls. While most of the results are statistically significant, the only coefficient that is economically significant is remaining in the same program of study in the second year of university. Focusing on this measure and the preferred specification (column 5), a 10 point increase in rank leads to a 1.9 percentage point increase in the likelihood of remaining in the same program of study and in the same university.

\section{Figure 8 and 9 approximately here}

In Figures 8 and 9, we depict the marginal effects of rank on the other outcomes. Across the distribution of HS GPA, all of these graphs show a similar pattern: a u-shaped relationship with stronger positive effects at the bottom and top of the distribution, and weaker positive effects in the middle. For instance, students at the $10^{\text {th }}$ and $90^{\text {th }}$ percentiles are statistically significantly more likely to stay in their program by about 2.6 percentage points, whereas the effect is 1.2 percentage points at the median. We also estimate a statistically significant effect of 1.8 percentage points at the $10^{\text {th }}$ percentile, and an insignificant effect of 1 percentage point at the 
$90^{\text {th }}$ percentile. For credit completions and staying at the university we estimate the same ushaped pattern, but all results are insignificant. We show in Appendix Figures A1 and A2 that the u-shaped pattern for staying in program and degree completion remains intact when we restrict the sample to those who remain in the school after year 1, though the magnitudes are slightly smaller.

Figures 8 and 9 also depict the heterogeneity in the rank effects across program of study and gender. The two most notable result is the increased likelihood of staying in the business program when ranked higher, and the larger effect of degree attainment for men. Otherwise, there are mostly no statistically significant differences in these effects across gender or programs. To summarize, a higher entry rank has a moderately positive effect on GPA, a positive effect on staying in a program that is most pronounced among lowest- and highest-ranked students, and an increase in the likelihood of graduation among the lowest ranked students. It is useful to compare our results to Elsner, Isphording, and Zölitz (2019), the most closely related research to ours. In terms of achievement, our results are larger by roughly a factor of 10. For graduation, we both estimate similar small average effects. The achievement differences are not likely driven by the econometric specification, since it is virtually the same in both papers. It could instead be their paper focuses on performance in a specific course, whereas we focus on GPA. Another contributing factor might be differences between the Netherlands and Canada in terms of their postsecondary institutions. 
It is worth drawing comparisons between our findings and those of the academic match literature, which examines the consequences of a misalignment between a student's academic ability and the quality of their college. Overmatched students are those who attend a college that is above their academic ability, and under-matched students are the reverse. One of the ways academic match might affect outcomes is through rank: overmatched students will rank low at their college, while under-matched students rank high. That literature suggests that while student academic ability and college quality each have independent positive effects on academic and labor market outcomes, being over or under-matched to a college has very little effect except that overmatched students transfer down in terms of their academic program, and under-matched students transfer up. ${ }^{18}$

Our finding of a small to moderate average effects of rank lines up with the general lack of estimated academic match effects. However, we also find that students ranked near the bottom - who are overmatched - are more likely to stay in their program and graduate in six years when they increase their rank (improve their match). Thinking about this effect in reverse, increasing the degree of overmatch leads to more program switching and a lower likelihood of graduating in six years. The result fits with the academic match result that overmatched students are more likely to switch programs, though we do not know in our case whether students are transferring up or down. We also find that under matched students at the $90^{\text {th }}$ percentile are also more likely to stay in their program by increasing their rank. This may be less driven by match, 
and more by students at the top receiving extra attention by instructors. Nevertheless, there are likely connections between rank and match effects.

The moderate average effects on academic outcomes implies that students in near the middle of the distribution who attend a selective institution, and therefore face a lower rank in their entry class all else equal, are not likely to suffer significant consequences from that decision. Given the estimated positive effects of college quality on outcomes in the literature, such students are likely better off attending a more selective institution and benefiting from the positives that go along with that choice. One exception is that students who are at the very top of the distribution in one institution would face more substantial academic penalties to switching to a more selective school given the strong positive effects we estimate at the $90^{\text {th }}$ percentile. For these students, the benefits of college quality may not outweigh the losses from a lower rank. Course-Specific Rankings

Our main analysis ranks students according to their HS GPA, which measures a combination of cognitive and non-cognitive skills averaged over a series of courses. One might ask whether some of the specific courses that comprise that average drive the relationship between rank and our outcomes. ${ }^{19}$ For instance, does a higher ranking in math have a stronger correlation with performance in an engineering program than a student's HS GPA rank? Does a student's English ranking have any bearing on their performance in an engineering program? We explore questions like these in Table 5, where we regress a student's university GPA on ranking from the following individual courses: English, calculus, Mathematics of Data Management (MDM), 
chemistry, physics, and biology. ${ }^{20}$ We perform these regressions separately by entry program, and only include courses that most students in the program have taken. For instance, when we run the regression for arts students, we only include English rank because most of these students have not taken math or science courses. For science students, on the other hand, we include rankings in all courses because upper level English is a requirement in Ontario high schools, and math and science classes are prerequisites for university science programs. In addition to the course specific rankings, we also hold constant in all regressions the underlying grade in the course that determines the ranking, just as we did in our main specification when we controlled for HS GPA.

\section{Table 5 approximately here}

Column 1 of Table 5 shows that a 1 decile increase in English rank boosts university GPA by 0.05 standard deviations, which is about half the size of our main result. When we explore science programs in column 2, calculus, MDM, and chemistry have similar statistically significant positive effects on university GPA, whereas English ranking has a small effect. Other courses have statistically insignificant effects on science grades in university. For business, we see that MDM has the biggest impact on performance, with a decile increase in rank boosting university GPA by 0.035 standard deviations. Finally, in engineering ranking higher in calculus, MDM, and chemistry boost university GPA by roughly 0.03 standard deviations.

Taking these results as a whole, the most consistent finding is that ranking in math courses has a significant effect on outcomes in science, business, and engineering, which are all 
areas where quantitative skills are important. Interestingly, the only science course that impacts achievement in science and engineering programs is chemistry. Also interesting is that in engineering, ranking better in English brings down university GPA. Relating this back to the mechanisms underlying the BFLPE, it might be that students who rank higher in English form a worse academic self-concept about their skills in engineering programs, which negatively affects their performance. That is, being relatively good at English might instill some self-doubt among engineering students that could affect their performance. It might also be that otherwise equivalent engineers who rank higher in English get less attention from their instructors.

\section{Robustness}

In this section we check the robustness of our results to changes in the peer group within which we rank students. First, we broaden the group and rank students compared to everyone in the university in a particular year. The estimates in Table 6 show that our results are relatively insensitive to this change in the ranking group across most outcomes. In particular, the university GPA results and persistence in university program are only slightly higher than in Tables 3 and 4 . The most notable exception is that we now estimate a 2 percentage point increase in the likelihood of graduating in six years with a decile increase in rank.

\section{Table 6 approximately here}

We also test the robustness to tightening the peer group. Our main results rank students within four broad programs: arts, science, business, engineering. We grouped students in this way for two key reasons: first, specific programs at Ontario universities are very granular, so it 
would be unmanageable to rank within those programs, and create some very small sized peer groups. Second, in one of the universities in our sample, year 1 programs line up with the broad groups we define above, so for consistency we regrouped everyone in that way. But, because our identifying variation in rank occurs within the program and university, we do not need the groups to line up across schools. As such, we present some results with disaggregated groups. To keep that set manageable, we use program categories defined by OUAC. There are a total of 23 categories, though only 10 appear in our sample because they fall within the broad groups we defined previously. ${ }^{21}$ As we show in Table 7, the results using these more detailed groups are remarkably similar to those in Tables 3 and 4.

\section{Table 7 approximately here}

\section{Conclusion}

There are many important factors students must consider when choosing among post-secondary institutions and programs. It has recently been suggested in popular media that among those factors, students should pay serious attention to their ability relative to others in each school, since ranking lower could have very a negative effect on progression through a degree program. This implies that the conventional wisdom when selecting among universities, which says that they should attend the best institution to which they are admitted, might actually lead to worse outcomes for some students.

We study the effect of rank at entry to post-secondary on several outcomes, and for the average student we find that ranking higher modestly increases both year 1 university GPA and 
the likelihood of staying in the same program beyond year 1, but has insignificant effects on credits completed, registering in the university beyond year 1 , and completing a degree at that university within six years. We see more in the tails of the distribution: rank has the largest positive effect on university GPA for those ranked highest, while it has the largest positive effect on persistence within program and degree completion among those ranked lowest. Our results are robust to across various specifications, including one that controls for differences in the average characteristics across universities, programs, and time.

Our results imply that attending a selective institution where a student ranks lower than at less selective schools could negatively impact their persistence at that university or their GPA, especially if they would otherwise be in the top or bottom of the distribution. For the student in the middle of the distribution, however, given the positive effects of college quality on outcomes reported in the literature, attending a selective institution could offer net benefits. 


\section{References}

Abdulkadiroglu, Atila, Joshua Angrist, and Parag Pathak. 2014. The Elite Illusion: Achievement Effects at Boston and New York Exam Schools. Econometrica 82 (1): pp. 137-96

Arcidiacono, Peter, Esteban M. Aucejo, and V. Joseph Hotz. 2016. University Differences in the Graduation of Minorities in STEM Fields: Evidence from California. American Economic Review, 42: pp. 93-108.

Betts, Julian R., and Darlene Morell. 1999. The Determinants of Undergraduate Grade Point Average: The Relative Importance of Family Background, High School Resources, and Peer Group Effects. The Journal of Human Resources, 34 (2): pp. 268-93.

Black, Dan. A., and Jeffrey A. Smith. 2004. How robust is the evidence on the effects of college quality? Evidence from matching. Journal of econometrics. 121(1-2): pp. 99-124.

Bowen, William, and Derek Bok. 1998. The Shape of the River: Long-Term Consequences of Considering Race in College and University Admissions. Princeton, NJ: Princeton University Press.

Bowen, Willian, Matthew Chingos, and Michael McPherson. 2009. Crossing the Finish Line: Completing College at America's Public Universities. Princeton, NJ: Princeton University Press. Bui, Sa, Steven Craig, and Scott A. Imberman. 2014. Is Gifted Education a Bright Idea? Assessing the Impact of Gifted and Talented Programs on Students. American Economic Journal: Economic Policy, 6(3): pp. 30-62.

Camara, Wayne J., and Gary Echternacht. 2000. The SAT I and High School Grades: Utility in 
Predicting Success in College. College Board Research Notes, RN10: pp. 1-12.

Catsambis, Sophia, Lynn N. Mulkey, and Robert L. Crain. 2001. For Better or for Worse? A Nationwide Study of the Social Psychological Effects of Gender and Ability Grouping in Mathematics. Social Psychology of Education, 5(1): pp. 83-115.

Chingos, Matthew. 2012. Graduation Rates at America’s Universities: What We Know and What We Need to Know. In Getting to Graduation: The Completion Agenda in Higher Education, edited by Andrew P. Kelly and Mark Schneider. Baltimore, MD: Johns Hopkins University Press, pp. 48-70.

Cohn, Elchanan, Sharon Cohn, Donald C. Balch, and James Bradley Jr. 2004. Determinants of Undergraduate GPAs: SAT Scores, High-School GPA and High-School Rank. Economics of Education Review, 23 (6): pp. 577-586.

Dillon, Eleanor Wiske, and Jeffrey A. Smith. 2018. The Consequences of Academic Match Between Students and Colleges. NBER Working Paper No. 25069.

Dai, David Yun, and Anne N. Rinn. 2008. The Big-Fish-Little-Pond Effect: What Do We Know and Where Do We Go from Here? Educational Psychology Review, 20(3): pp. 283-317. Dale, Stacy Berg, and Alan B. Krueger. 2002. Estimating the payoff to attending a more selective college: An application of selection on observables and unobservables. The Quarterly Journal of Economics, 117(4): pp. 1491-527.

Dale, Stacy Berg, and Alan B. Krueger. 2014. Estimating the Effects of College Characteristics over the Career Using Administrative Earnings Data. Journal of Human Resources, 49(2): pp. 
323-58.

Denning, Jeffrey T., Richard Murphy, and Felix Weinhardt. 2018. Class Rank and Long-Run

Outcomes. IZA Discussion Paper 11808.

Dooley, Martin D., A. Abigail Payne, and A. Leslie Robb. 2011. Understanding the

Determinants of Persistence and Academic Success in University: An Exploration of Data from

Four Ontario Universities. Toronto: Higher Education Quality Council of Ontario.

Elsner, Benjamin, and Ingo E. Isphording. 2017. A Big Fish in a Small Pond: Ability Rank and

Human Capital Investment. Journal of Labor Economics, 35 (3): pp. 787-828.

Elsner, Benjamin, and Ingo E. Isphording. 2018. Rank, Sex, Drugs and Crime. Journal of Human

Resources, 53 (2): pp. 356-381.

Elsner, Benjamin, Ingo E. Isphording, and Ulf Zölitz. 2019. Achievement Rank Affects

Performance and Major Choices in College. University of Zurich Working Paper.

Gibbons, Frederick X., Camilla Persson Benbow, and Meg Gerrard. 1994. From Top Dog to

Bottom Half: Social Comparison Strategies in Response to Poor Performance. Journal of

personality and social psychology, 67 (4): pp. 638-52.

Gladwell, Malcolm. 2013. David and Goliath: Underdogs, Misfits, and the Art of Battling

Giants. Little, Brown and Company.

Gneezy, Uri, Muriel Niederle, and Aldo Rustichini. 2003. Performance in Competitive

Environments: Gender Differences. Quarterly Journal of Economics, 118(3): pp. 1049-74. 
Hoekstra, Mark. 2009. The Effect of Attending the Flagship State University on Earnings: A Discontinuity-Based Approach. The Review of Economics and Statistics, 91(4): pp. 717-24. Hoxby, Caroline M. 2000a. Peer Effects in the Classroom: Learning from Gender and Race Variation. NBER Working Paper 7867.

Hoxby, Caroline M. 2000b. The Effects of Class Size on Student Achievement: New Evidence from Population Variation. Quarterly Journal of Economics, 115 (4): pp. 1239-85.

Light, Audrey, and Wayne Strayer. 2000. Determinants of college completion: School quality or student ability?. Journal of Human Resources 35 (2): pp. 299-332.

Long, Mark C. 2008. College quality and early adult outcomes. Economics of Education Review, 27(5): pp. 588-602.

Long, Mark C. 2010. Changes in the returns to education and college quality. Economics of Education Review, 29 (3): pp. 338-347.

Lüdtke, Oliver, Olaf Köller, Herbert W. Marsh, and Ulrich Trautwein. 2005. Teacher Frame of Reference and the Big-Fish-Little-Pond Effect. Contemporary Educational Psychology 30(3): pp. 263-85.

Manski, Charles F. 1993. Identification of Endogenous Social Effects: The Reflection Problem. The Review of Economic Studies, 60 (3): pp. 531-42.

Marsh, Herbert W. 1987. The Big-Fish-Little-Pond Effect on Academic Self-Concept. Journal of Educational Psychology, 79 (3): pp. 280-95.

Marsh, Herbert W. 1994. Using the National Longitudinal Study of 1988 to Evaluate Theoretical 
Models of Self-Concept: The Self-Description Questionnaire. Journal of educational

Psychology, 86 (3): pp. 439-56.

Marsh, Herbert W., Danuta Chessor, Rhonda Craven, and Lawrence Roche. 1995. The Effects of Gifted and Talented Programs on Academic Self-Concept: The Big Fish Strikes Again.

American Educational Research Journal, 32 (2): pp. 285-319.

Marsh, Herbert W., and Kit-Tai Hau. 2003. Big-Fish-Little-Pond Effect on Academic Self

Concept: A Cross-Cultural (26-Country) Test of the Negative Effects of Academically Selective

Schools. American psychologist, 58 (3): pp. 364-76.

Marsh, Herbert W., Chit-Kwong Kong, and Kit-Tai Hau. 2000. Longitudinal Multilevel Models

of the Big-Fish-Little-Pond Effect on Academic Self-Concept: Counterbalancing Contrast and

Reflected-Glory Effects in Hong Kong Schools. Journal of personality and social psychology, 78

(2): pp. 337-49.

Marsh, Herbert W., Olaf Köller, and Jurgen Baumert. 2001. Reunification of East and West

German School Systems: Longitudinal Multilevel Modeling Study of the Big-Fish-Little-Pond

Effect on Academic Self-Concept. American Educational Research Journal, 38(2): pp. 321-50.

Marsh, Herbert W., and John W. Parker. 1984. Determinants of Student Self-Concept: Is It

Better to Be a Relatively Large Fish in a Small Pond Even If You Don't Learn to Swim as Well?

Journal of Personality and Social Psychology, 47(1): pp. 213-31.

Marsh, Herbert W., and Kenneth J. Rowe. 1996. The Negative Effects of School-Average

Ability on Academic Self-Concept: An Application of Multilevel Modelling. Australian Journal

This article is protected by copyright. All rights reserved. 
of Education, 40(1): pp. 65-87.

Marsh, Herbert W., Marjorie Seaton, Ulrich Trautwein, Oliver Ludtke, Kit-Tai Hau, Alison J.

O’Mara, and Rhonda G. Craven. 2008. The Big-Fish-Little-Pond-Effect Stands up to Critical

Scrutiny: Implications for Theory, Methodology, and Future Research. Educational Psychology

Review. 20(3): pp. 319-50.

Marsh, Herbert W., Ulrich Trautwein, Oliver Ludtke, Jurgen Baumert, and Olaf Koller. 2007.

The Big-Fish-Little-Pond Effect: Persistent Negative Effects of Selective High Schools on Self

Concept after Graduation. American Educational Research Journal 44(3): pp. 631-69.

Mattern, Krista D., Emily J. Shaw, and Jennifer L. Kobrin. 2010. Academic fit: is the right

school the best school or is the best school the right school?. Journal of Advanced

Academics, 21(3): pp. 368-391

Murphy, Richard, and Felix Weinhardt. 2018. Top of the Class: The Importance of Ordinal

Rank. NBER Working Paper 24958.

Niederle, Muriel, and LiseVesterlund, L. 2011. Gender and Competition. Annual Review of

Economics, 3(1): pp. 601-30.

Pop-Eleches, Cristian, and Miguel Urquiola. 2013. Going to a Better School: Effects and

Behavioral Responses. American Economic Review, 103(4): pp. 1289-1324.

Rinn, Anne N. 2007. Effects of Programmatic Selectivity on the Academic Achievement, Academic Self-Concepts, and Aspirations of Gifted College Students. Gifted Child Quarterly, 51(3): pp 232-45. 
Rothstein, Jesse M. 2004. College Performance Predictions and the SAT. Journal of Econometrics, 121(1-2): pp. 297-317.

Sacerdote, Bruce. 2001. Peer Effects in Education: How Might They Work, How Big Are They and How Much Do We Know Thus Far? Handbook of the Economics of Education 3, pp. 249 77.

Seaton, Marjorie, Herbert W. Marsh, and Rhonda G. Craven. 2009. Earning Its Place as a Pan Human Theory: Universality of the Big-Fish-Little-Pond Effect across 41 Culturally and Economically Diverse Countries. Journal of Educational Psychology, 101(2): pp. 403-19. Seaton, Marjorie, Herbert W. Marsh, and Rhonda G. Craven. 2010. Big-Fish-Little-Pond Effect Generalizability and Moderation—Two Sides of the Same Coin. American Educational Research Journal, 47(2): pp. 390-433.

Seaton, Marjorie, Herbert W. Marsh, Florence Dumas, Pascal Huguet, Jean-Marc Monteil, Isabelle Regner, Hart Blanton, Abraham P. Buunk, Frederick X. Gibbons, Hans Kuyper, Jerry Suls, and Ladd Wheeler. 2008. In Search of the Big Fish: Investigating the Coexistence of the Big-Fish-Little-Pond Effect with the Positive Effects of Upward Comparisons. British Journal of Social Psychology, 47(1): pp. 73-103.

Statistics Canada. (2019) Table 37-10-0018 01 - Postsecondary enrolments, by registration status, institution type, status of student in Canada and sex. Retrieved from https://doi.org/10.25318/3710001801-eng

Tymms, Peter A. 2001. Test of the Big Fish in a Little Pond Hypothesis: An Investigation into 
the Feelings of Seven-Year-Old Pupils in School. School Effectiveness and School Improvement, 12(2): pp. 161-81.

Zeidner, Moshe, and Esther Jane Schleyer. 1999. The Big-Fish-Little-Pond Effect for Academic Self-Concept, Test Anxiety, and School Grades in Gifted Children. Contemporary Educational Psychology, 24(4): pp. 305-29.

Zwick, Rebecca, and Jennifer Greif Green. 2007. New Perspectives on the Correlation of SAT

Scores, High School Grades, and Socioeconomic Factors. Journal of Educational Measurement, 44(1): pp. 23-45.

This article is protected by copyright. All rights reserved. 


\footnotetext{
${ }^{1}$ Several authors have studied the role of ASC on student performance using data from many countries. See, among others, Marsh, 1987; Marsh, 1994; Gibbons et. al, 1994; Marsh et. al, 1995; Marsh and Rowe, 1996; Zeidner and Schleyer, 1998; Marsh et. al., 2000; Tymms, 2001, et al. Marsh, 2001; Castambis et. al, 2001; Marsh and Hau, 2003; Lüstke et al., 2005; Rinn, 2007; Seaton et. al, 2008; Seaton et. al, 2009; Seaton et. al. 2010

${ }^{2}$ In their critique, they appeal to Social Comparison Theory (SCT), which is a psychological theory in which individuals compare themselves against others for the purpose of self-evaluation.

${ }^{3}$ Elsner and Isphording (2018) use a similar empirical strategy to show that being ranked higher on ability lowers the likelihood of smoking, drinking, having unprotected sex, and fighting.

${ }^{4}$ Drewes and Michael (2006) show that students are more likely to apply to higher ranked undergraduate and comprehensive universities, but less likely to apply to higher ranked medical \doctoral universities.

${ }^{5}$ OUAC separates applicants into two groups. 101 students are those who apply directly from an Ontario high school. 105 students are all other applicants, including those from outside Ontario, those who have been out of high school form more than 7 months, and those who have previously attended a postsecondary institution.

${ }^{6}$ Our sample therefore excludes applicants from other provinces, Ontario students who applied while they were not in high school, and international applicants. These three groups combined amount to about $10 \%$ of students at Ontario universities.

${ }^{7}$ Programs that did not fit into one of these categories are not used in the analysis. For example, fine arts, journalism, and education (among others) are not included in the analysis. Economics is included in Arts, as most economics programs in Canada fall within that faculty.

${ }^{8}$ Also note that some universities have a co-op component to their academic programs, and as such many of its students do not follow the typical fall-winter academic schedule with summers off. This does not have an effect on most of our outcomes because students do not begin co-op until year two. For the graduation outcome, we focus on completion in six years rather than four or five.

${ }^{9}$ Dissemination Areas are a Census geography created by Statistics Canada. It is the lowest level of aggregation for which publically available data is produced, and contains roughly 700 households on average. 10 The number of students used in the regressions is smaller when the outcome is registering in a university or program in year 2 because we need to observe the following years' data to know whether the student is there or not. Likewise, when obtaining the degree in six years is the outcome, we need to observe students across six years to know whether they obtain their degree. Having to observe students over different lengths of time reduces the sample size for those outcomes. Appendix Table A2 shows the average characteristics for the different subsamples used in these regressions. In results available upon request, we estimate our preferred specification on the smallest of the three subsamples and show that the results are qualitatively the same as those in Tables 3 and 4, though smaller in magnitude for the university GPA outcome. Thus, if there is any effect of the difference in sample, it is to attenuate the effects.

${ }^{11}$ For this outcome and for degree completion, we also report regression estimates where we drop students who are not observed in year 2 , and compare them to our main results.

${ }^{12}$ See section III for a more detailed description of the top six courses and their importance in the application process.

13 The data for all applicants comes from the OUAC database. In computing this average, we exclude students who score below $50 \%$ because these students do not appear in our analysis sample. Such a low average means there is a low probability of being admitted to any university in Ontario. This effectively assumes these students should not have submitted an application to OUAC.

${ }^{14}$ See Appendix A for a more detailed description of this exercise.
} 
15 The subscript $n$ (i) refers to neighborhood $n$ in which person i lives. The goal is to highlight that while the variation is at the neighborhood level, it depends on the neighborhood in which person i resides.

16 To give some context for the size of a 10 point change in rank in terms of standardized student test scores at various points in the distribution, we first computed the test score deciles for each

university/program/year combination, took the difference in scores between each decile, then averaged those differences together. From this, a 10 point increase in rank means: a 1.27 standard deviation (SD) increase in scores at the minimum; a 22 SD increase at the first decile; roughly a 15 SD increase for deciles 2 through 6; a .20 SD increase at decile 7; a .27 SD increase at decile 8; a .83 SD increase at decile 9.

${ }^{17}$ Note that the "overall" effect reported in this figure is slightly different from the main effect in Table 3 because it is the marginal effect evaluated at the average from the following flexible specification

$$
\begin{gathered}
y_{i}=\alpha_{0}+\sum_{j=1}^{3} \alpha_{j} \operatorname{rank}_{i}^{j}+\sum_{j=0}^{3} \pi_{j} \operatorname{rank}_{i}^{j} *\left(\text { fem }_{i}+\operatorname{prog}_{i}+f e m * \operatorname{prog}_{i}\right)+\sum_{j=1}^{20} \beta_{j} h s g p a_{i}^{v j}+\theta_{1} x_{i}+\theta_{2} z_{n(i)} \\
+\delta_{p s(i)}+\mu_{t}+\varepsilon_{i}
\end{gathered}
$$

${ }^{18}$ For research on the effects of academic match, see Arcidiacono et. al. (2016), Bowen and Bok (1998), Bowen et. al. (2009), Chingos (2012), Dillon and Smith (2018), Light and Strayer (2000), Mattern et. al. (2010). Some of those research papers also examine the independent effects of college quality and academic ability, in addition to Black and Smith (2004), Dale and Krueger (2002, 2014), Hoekstra (2009), Long (2008, 2010).

${ }^{19}$ Appendix B also explores additional robustness and ranking options.

${ }^{20} \mathrm{MDM}$ is an introductory course in statistics and probability, covering things like data collection, summary statistics, combinatorics, probability, and the normal distribution.

21 These programs used in the sample are:, arts, science, business, physics, engineering, environment, health science, music, nursing, and math. Those excluded from the sample are agriculture, architecture, education, fine art, forestry, journalism, land architecture, rehab, social work, other administrative, other degree, preliminary year, and diploma. 
Table 1: Summary Statistics for Year 1 University GPA

\begin{tabular}{|c|c|c|c|c|c|c|}
\hline & & $\begin{array}{l}\text { Number of } \\
\text { Students }\end{array}$ & Mean & $\begin{array}{l}\text { Standard } \\
\text { Deviation }\end{array}$ & $\begin{array}{l}\text { 25th } \\
\text { Percentile }\end{array}$ & $\begin{array}{l}\text { 75th } \\
\text { e Percentile }\end{array}$ \\
\hline & & $(1)$ & $(2)$ & (3) & (4) & $(5)$ \\
\hline \multicolumn{2}{|c|}{ All Universities } & 114262 & 6.88 & 2.60 & 5.00 & 8.90 \\
\hline \multirow[t]{4}{*}{ University A } & Overall & 22274 & 7.02 & 2.22 & 5.60 & 8.60 \\
\hline & Arts & 11723 & 6.68 & 2.22 & 5.22 & 8.30 \\
\hline & Science & 2738 & 6.68 & 2.49 & 5.00 & 8.45 \\
\hline & Business & 7813 & 7.66 & 1.97 & 6.40 & 9.10 \\
\hline \multirow[t]{5}{*}{ University B } & Overall & 30285 & 6.87 & 2.45 & 5.18 & 8.70 \\
\hline & Arts & 11442 & 6.37 & 2.40 & 4.73 & 8.10 \\
\hline & Science & 10390 & 7.62 & 2.43 & 5.90 & 9.55 \\
\hline & Business & 3828 & 6.82 & 2.17 & 5.40 & 8.40 \\
\hline & Engineering & 4625 & 6.48 & 2.43 & 4.66 & 8.24 \\
\hline \multirow[t]{4}{*}{ University C } & Overall & 34626 & 6.95 & 2.75 & 5.00 & 9.00 \\
\hline & Arts & 9161 & 7.12 & 2.60 & 5.50 & 9.00 \\
\hline & Science & 18583 & 6.79 & 2.78 & 5.00 & 9.00 \\
\hline & Engineering & 6882 & 7.15 & 2.85 & 5.47 & 9.48 \\
\hline \multirow[t]{5}{*}{ University D } & Overall & 27077 & 6.67 & 2.82 & 5.00 & 9.00 \\
\hline & Arts & 12388 & 6.29 & 2.75 & 4.91 & 8.00 \\
\hline & Science & 9084 & 7.39 & 2.84 & 5.00 & 10.00 \\
\hline & Business & 3746 & 6.35 & 2.63 & 5.00 & 8.00 \\
\hline & Engineering & 1859 & 6.41 & 2.89 & 4.71 & 8.25 \\
\hline
\end{tabular}

Notes: GPA is calculated at the end of year 1 in university and is on a 12 point scale.

This article is protected by copyright. All rights reserved. 
Table 2: Average Statistics for Alternative University Outcomes

\begin{tabular}{|c|c|c|c|c|c|c|c|}
\hline Panel A & \multicolumn{4}{|c|}{ All Universities } & & & \\
\hline \multirow{5}{*}{$\begin{array}{l}\text { Credits Year } 1 \\
\text { Enroll in Year } 2 \text { of } \\
\text { University } \\
\text { Remains in Program in } \\
\text { Year } 2 \\
\text { Degree Completion within } \\
6 \text { years }\end{array}$} & $\begin{array}{c}\text { Mea } \\
\mathrm{n}\end{array}$ & SD & $\begin{array}{c}\text { Minimu } \\
\mathrm{m}\end{array}$ & $\begin{array}{c}\text { Maxim } \\
\text { um }\end{array}$ & & & \\
\hline & 4.95 & 0.93 & 0 & 10 & & & \\
\hline & 0.94 & 0.24 & 0 & 1 & & & \\
\hline & 0.87 & 0.34 & 0 & 1 & & & \\
\hline & 0.82 & 0.39 & 0 & 1 & & & \\
\hline \multirow[t]{3}{*}{ Panel B } & \multicolumn{3}{|c|}{ University A } & \multicolumn{4}{|c|}{ University B } \\
\hline & \multicolumn{3}{|c|}{ Outcome Mean } & \multicolumn{4}{|c|}{ Outcome Mean } \\
\hline & Arts & $\begin{array}{c}\text { Scien } \\
\text { ce }\end{array}$ & Business & Arts & $\begin{array}{c}\text { Scien } \\
\text { ce }\end{array}$ & $\begin{array}{c}\text { Busine } \\
\text { ss }\end{array}$ & $\begin{array}{c}\text { Engineeri } \\
\text { ng }\end{array}$ \\
\hline $\begin{array}{l}\text { Credits Year } 1 \\
\text { Enroll in Year } 2 \text { of }\end{array}$ & 4.68 & 4.63 & 4.96 & 4.76 & 5.09 & 4.97 & 5.64 \\
\hline $\begin{array}{l}\text { University } \\
\text { Remains in Program in }\end{array}$ & 0.92 & 0.92 & 0.96 & 0.91 & 0.96 & 0.93 & 0.95 \\
\hline $\begin{array}{l}\text { Year } 2 \\
\text { Degree Completion within }\end{array}$ & 0.84 & 0.73 & 0.83 & 0.86 & 0.91 & 0.81 & 0.91 \\
\hline 6 years & 0.79 & 0.78 & 0.89 & 0.78 & 0.89 & 0.85 & 0.82 \\
\hline \multirow[t]{3}{*}{ Panel C } & \multicolumn{3}{|c|}{ University C } & \multicolumn{4}{|c|}{ University D } \\
\hline & \multicolumn{3}{|c|}{ Outcome Mean } & \multicolumn{4}{|c|}{ Outcome Mean } \\
\hline & Arts & $\begin{array}{c}\text { Scien } \\
\text { ce }\end{array}$ & $\begin{array}{l}\text { Engineeri } \\
\text { ng }\end{array}$ & Arts & $\begin{array}{c}\text { Scien } \\
\text { ce }\end{array}$ & $\begin{array}{c}\text { Busine } \\
\text { ss }\end{array}$ & $\begin{array}{l}\text { Engineeri } \\
\text { ng }\end{array}$ \\
\hline $\begin{array}{l}\text { Credits Year } 1 \\
\text { Enroll in Year } 2 \text { of }\end{array}$ & 4.69 & 4.96 & 5.33 & 4.80 & 4.99 & 4.88 & 6.34 \\
\hline $\begin{array}{l}\text { University } \\
\text { Remains in Program in }\end{array}$ & 0.92 & 0.95 & 0.97 & 0.93 & 0.95 & 0.96 & 0.94 \\
\hline $\begin{array}{l}\text { Year } 2 \\
\text { Degree Completion within }\end{array}$ & 0.89 & 0.92 & 0.96 & 0.87 & 0.80 & 0.65 & 0.89 \\
\hline 6 years & 0.76 & 0.79 & 0.87 & 0.78 & 0.82 & 0.85 & 0.76 \\
\hline
\end{tabular}

Notes: see the text for definitions of the outcome measures. 
Table 3: Baseline Regressions for GPA in Year 1

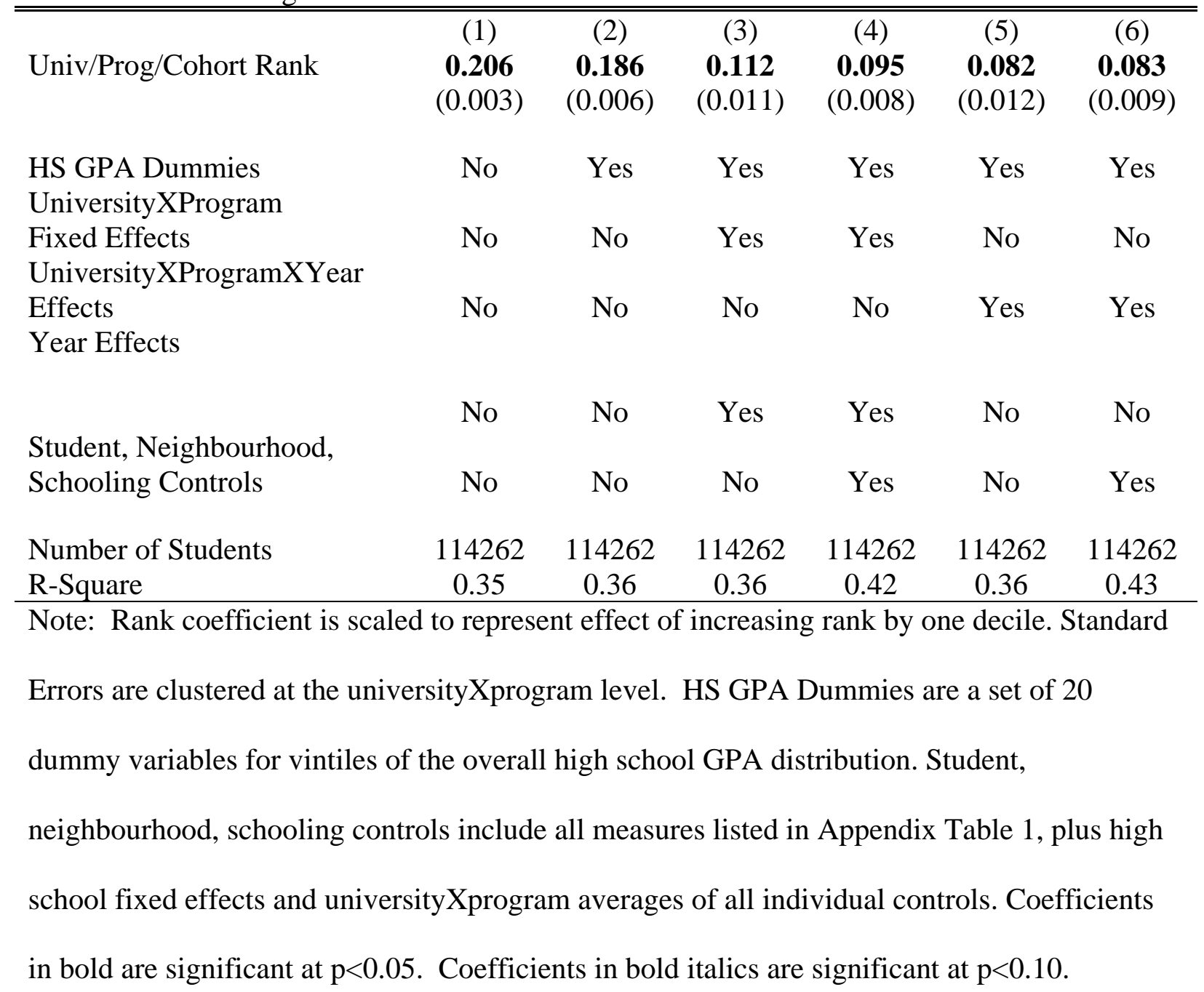

This article is protected by copyright. All rights reserved. 
Table 4: Regressions for Other Outcomes

\begin{tabular}{|c|c|c|c|c|c|c|c|c|}
\hline & \multicolumn{2}{|c|}{$\begin{array}{l}\text { Credit } \\
\text { Completions in } \\
\text { Year } 1\end{array}$} & \multicolumn{2}{|c|}{$\begin{array}{c}\text { Observed Registering } \\
\text { in Year } 2 \text { at the } \\
\text { University }\end{array}$} & \multicolumn{2}{|c|}{$\begin{array}{l}\text { Observed Remaining in } \\
\text { the same Program of } \\
\text { Study at the University in } \\
\text { Year } 2\end{array}$} & \multicolumn{2}{|c|}{$\begin{array}{l}\text { Observed Receiving } \\
\text { a Degree within } 6 \\
\text { years }\end{array}$} \\
\hline & (1) & (2) & (3) & (4) & (5) & (6) & (7) & (8) \\
\hline Univ/Prog/Cohort Rank & $\begin{array}{c}\mathbf{0 . 0 1 8} \\
(0.009)\end{array}$ & $\begin{array}{c}0.010 \\
(0.009)\end{array}$ & $\begin{array}{c}\mathbf{0 . 0 0 4} \\
(0.001)\end{array}$ & $\begin{array}{c}\mathbf{0 . 0 0 4} \\
(0.001)\end{array}$ & $\begin{array}{c}\mathbf{0 . 0 1 9} \\
(0.006)\end{array}$ & $\begin{array}{c}\mathbf{0 . 0 2 1} \\
(0.007)\end{array}$ & $\begin{array}{c}\mathbf{0 . 0 0 8} \\
(0.003)\end{array}$ & $\begin{array}{c}\mathbf{0 . 0 0 8} \\
(0.003)\end{array}$ \\
\hline $\begin{array}{l}\text { HS GPA Dummies } \\
\text { UniversityXProgram }\end{array}$ & Yes & Yes & Yes & Yes & Yes & Yes & Yes & Yes \\
\hline $\begin{array}{l}\text { Fixed Effects } \\
\text { UniversityXProgram }\end{array}$ & Yes & No & Yes & No & Yes & No & Yes & No \\
\hline $\begin{array}{l}\text { XYear Effects } \\
\text { Year Effects }\end{array}$ & No & Yes & No & Yes & No & Yes & No & Yes \\
\hline & Yes & No & Yes & No & Yes & No & Yes & No \\
\hline Schooling Controls & Yes & Yes & Yes & Yes & Yes & Yes & Yes & Yes \\
\hline Number of Students & 114262 & 114262 & 105585 & 105585 & 105585 & 105585 & 51615 & 51615 \\
\hline R-Square & 0.20 & 0.21 & 0.04 & 0.04 & 0.08 & 0.08 & 0.09 & 0.09 \\
\hline
\end{tabular}

Note: Rank coefficient is scaled to represent effect of increasing rank by one decile. Coefficients in bold italics are significant at

$\mathrm{p}<0.10$. Standard Errors are clustered at the universityXprogram level. HS GPA Dummies are a set of 20 dummy variables for 
vintiles of the overall high school GPA distribution. Student, neighbourhood, schooling controls include all measures listed in

Appendix Table 1, plus high school fixed effects and universityXprogram averages of all individual controls. Coefficients in bold are significant at $\mathrm{p}<0.05$. 
Table 5: GPA Regressions with Other Rankings

\begin{tabular}{lcccc}
\hline \hline & Arts & Science & Business & Engineering \\
English Ranking & & & & \\
& $\mathbf{0 . 0 5 6}$ & $\mathbf{0 . 0 0 8}$ & 0.007 & $\mathbf{- 0 . 0 2 9}$ \\
Calculus Ranking & $(0.006)$ & $(0.004)$ & $(0.009)$ & $(0.011)$ \\
& & $\mathbf{0 . 0 4 1}$ & 0.013 & $\mathbf{0 . 0 2 6}$ \\
MDM Ranking & & $(0.007)$ & $(0.009)$ & $(0.002)$ \\
& & $\mathbf{0 . 0 3 4}$ & $\mathbf{0 . 0 3 5}$ & $\mathbf{0 . 0 3 9}$ \\
Chemistry Ranking & & $(0.008)$ & $(0.006)$ & $(0.001)$ \\
& & $\mathbf{0 . 0 4 3}$ & & $\mathbf{0 . 0 2 7}$ \\
Physics Ranking & & $\mathbf{0 . 0 1 1 )}$ & & $(0.002)$ \\
& & $\mathbf{0 . 0 2 2}$ & & $\mathbf{0 . 0 0 9}$ \\
Biology Ranking & & 0.015 & & $(0.002)$ \\
& & $(0.015)$ & & \\
UniversityXProgram Fixed Effects & & & & \\
UniversityXProgramXYear Effects & Yes & Yes & Yes & Yes \\
Year Effects & No & No & No & No \\
Student, Neighbourhood, Schooling Controls & Yes & Yes & Yes & Yes \\
& Yes & Yes & Yes \\
Number of Students & 44449 & 10002 & 12478 & 9343 \\
R-Square & 0.278 & 0.576 & 0.368 & 0.482 \\
\hline Net Rak
\end{tabular}

Note: Rank coefficient is scaled to represent effect of increasing rank by one decile.

Standard Errors are clustered at the universityXprogram level. Student, neighbourhood, schooling controls include all measures listed in Appendix Table 1, plus high school fixed effects and universityXprogram averages of all individual controls. Regressions are run separately by entry program, and include the sample of students who have taken courses used in the regressions. Coefficients in bold are significant at $\mathrm{p}<0.05$. Coefficients in bold italics are significant at $\mathrm{p}<0.10$. 
Table 6: Rank Effects on Outcomes with Ranking by University/Cohort

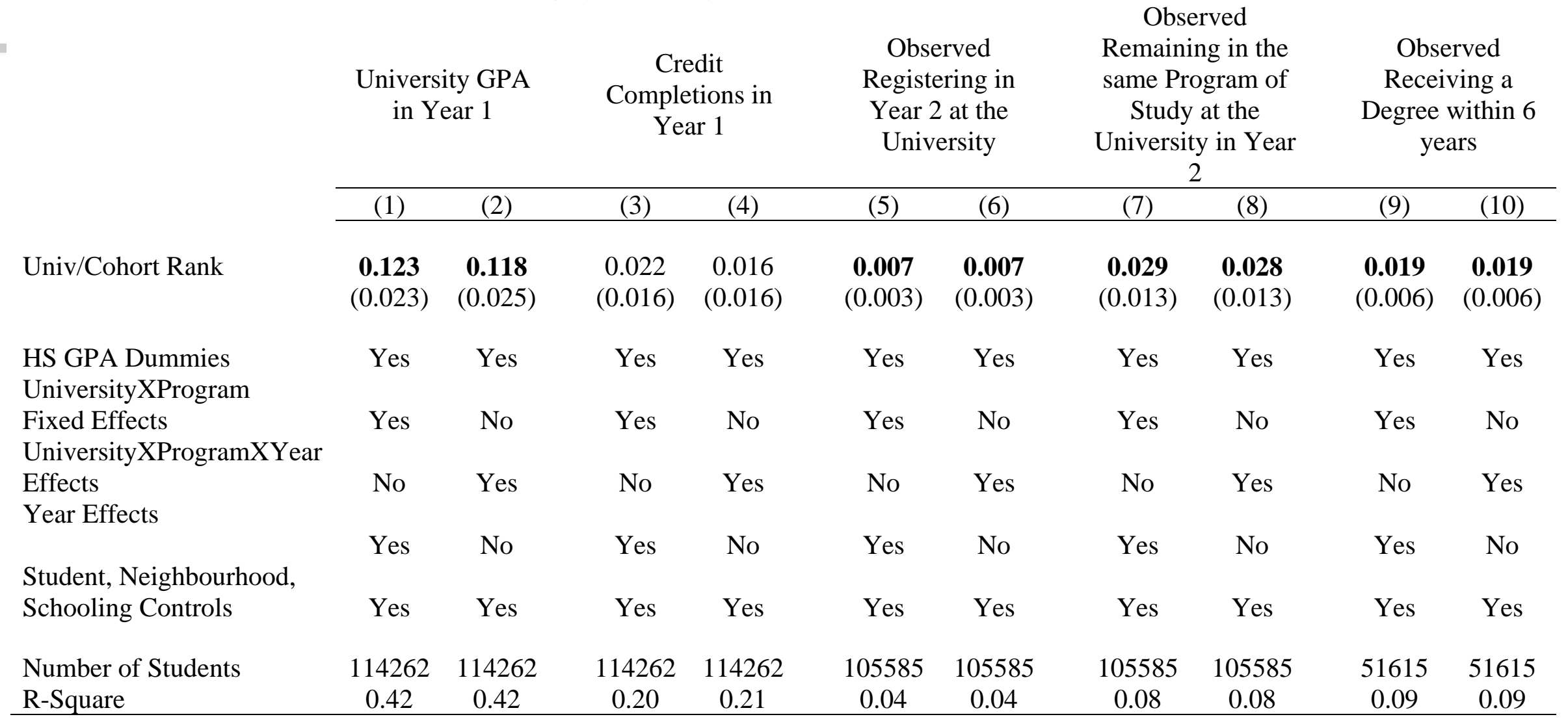

Note: Rank coefficient is scaled to represent effect of increasing rank by one decile. Standard Errors are clustered at the

universityXprogram level. Student, neighbourhood, schooling controls include all measures listed in Appendix Table 1 . The 
university/cohort rank measure ranks all students in the same university in the same year. Coefficients in bold are significant at $\mathrm{p}<0.05$.

Coefficients in bold italics are significant at $\mathrm{p}<0.10$.

This article is protected by copyright. All rights reserved. 
Table 7: Rank Effects on Outcomes using Detailed Program Information

\begin{tabular}{|c|c|c|c|c|c|c|c|c|c|c|}
\hline & \multicolumn{2}{|c|}{$\begin{array}{c}\text { University GPA } \\
\text { in Year } 1\end{array}$} & \multicolumn{2}{|c|}{$\begin{array}{c}\text { Credit } \\
\text { Completions in } \\
\text { Year } 1\end{array}$} & \multicolumn{2}{|c|}{$\begin{array}{l}\text { Observed } \\
\text { Registering in } \\
\text { Year } 2 \text { at the } \\
\text { University }\end{array}$} & \multicolumn{2}{|c|}{$\begin{array}{c}\text { Observed } \\
\text { Remaining in the } \\
\text { same Program of } \\
\text { Study at the } \\
\text { University in Year } \\
2\end{array}$} & \multicolumn{2}{|c|}{$\begin{array}{c}\text { Observed } \\
\text { Receiving a } \\
\text { Degree within } 6 \\
\text { years }\end{array}$} \\
\hline & $(1)$ & $(2)$ & (3) & (4) & (5) & (6) & $(7)$ & (8) & (9) & (10) \\
\hline Univ/Det Prog/Cohort Rank & $\begin{array}{c}\mathbf{0 . 0 8 1} \\
(0.007)\end{array}$ & $\begin{array}{c}\mathbf{0 . 0 6 9} \\
(0.009)\end{array}$ & $\begin{array}{c}0.019 \\
(0.014)\end{array}$ & $\begin{array}{c}0.018 \\
(0.016)\end{array}$ & $\begin{array}{c}\mathbf{0 . 0 0 3} \\
(0.001)\end{array}$ & $\begin{array}{c}\mathbf{0 . 0 0 3} \\
(0.001)\end{array}$ & $\begin{array}{c}\mathbf{0 . 0 1 6} \\
(0.006)\end{array}$ & $\begin{array}{c}\mathbf{0 . 0 2 0} \\
(0.006)\end{array}$ & $\begin{array}{c}\mathbf{0 . 0 0 8} \\
(0.003)\end{array}$ & $\begin{array}{c}\mathbf{0 . 0 0 9} \\
(0.003)\end{array}$ \\
\hline $\begin{array}{l}\text { HS GPA Dummies } \\
\text { UniversityXProgram }\end{array}$ & Yes & Yes & Yes & Yes & Yes & Yes & Yes & Yes & Yes & Yes \\
\hline $\begin{array}{l}\text { Fixed Effects } \\
\text { UniversityXProgramXYear }\end{array}$ & Yes & No & Yes & No & Yes & No & Yes & No & Yes & No \\
\hline $\begin{array}{l}\text { Effects } \\
\text { Year Effects }\end{array}$ & No & Yes & No & Yes & No & Yes & No & Yes & No & Yes \\
\hline & Yes & No & Yes & No & Yes & No & Yes & No & Yes & No \\
\hline Schooling Controls & Yes & Yes & Yes & Yes & Yes & Yes & Yes & Yes & Yes & Yes \\
\hline Number of Students & 114262 & 114262 & 114262 & 114262 & 105585 & 105585 & 105585 & 105585 & 51615 & 51615 \\
\hline R-Square & 0.44 & 0.44 & 0.23 & 0.24 & 0.04 & 0.04 & 0.09 & 0.09 & 0.09 & 0.10 \\
\hline
\end{tabular}


Note: Rank coefficient is scaled to represent effect of increasing rank by one decile. Coefficients in bold italics are significant at $\mathrm{p}<0.10$. Standard Errors are clustered at the universityXprogram level. Student, neighbourhood, schooling controls include all measures listed in Appendix Table 1. There are 21 disaggregated prorgams that make up the ranking for all specifications in this table. Coefficients in bold are significant at $\mathrm{p}<0.05$.

This article is protected by copyright. All rights reserved. 
Figure 1: Grade Distributions Across Time

Figure 2: The Effect of Normalized Rank on Normalized GPA

Figure 3: The Effect of Rank on Program Persistence

Figure 4: The Effect of Rank on Credits Completed

Figure 5: The Effect of Rank on University Persistence

Figure 6: The Effect of Rank on Degree Completion

Figure 7: Heterogeneity in the Effect of Rank on GPA

Figure 8: Heterogeneity in the Effect of Rank on Program Persistence and Degree Completion

Figure 9: Heterogeneity in the Effect of Rank on Credit Completion and University Persistence

This article is protected by copyright. All rights reserved. 


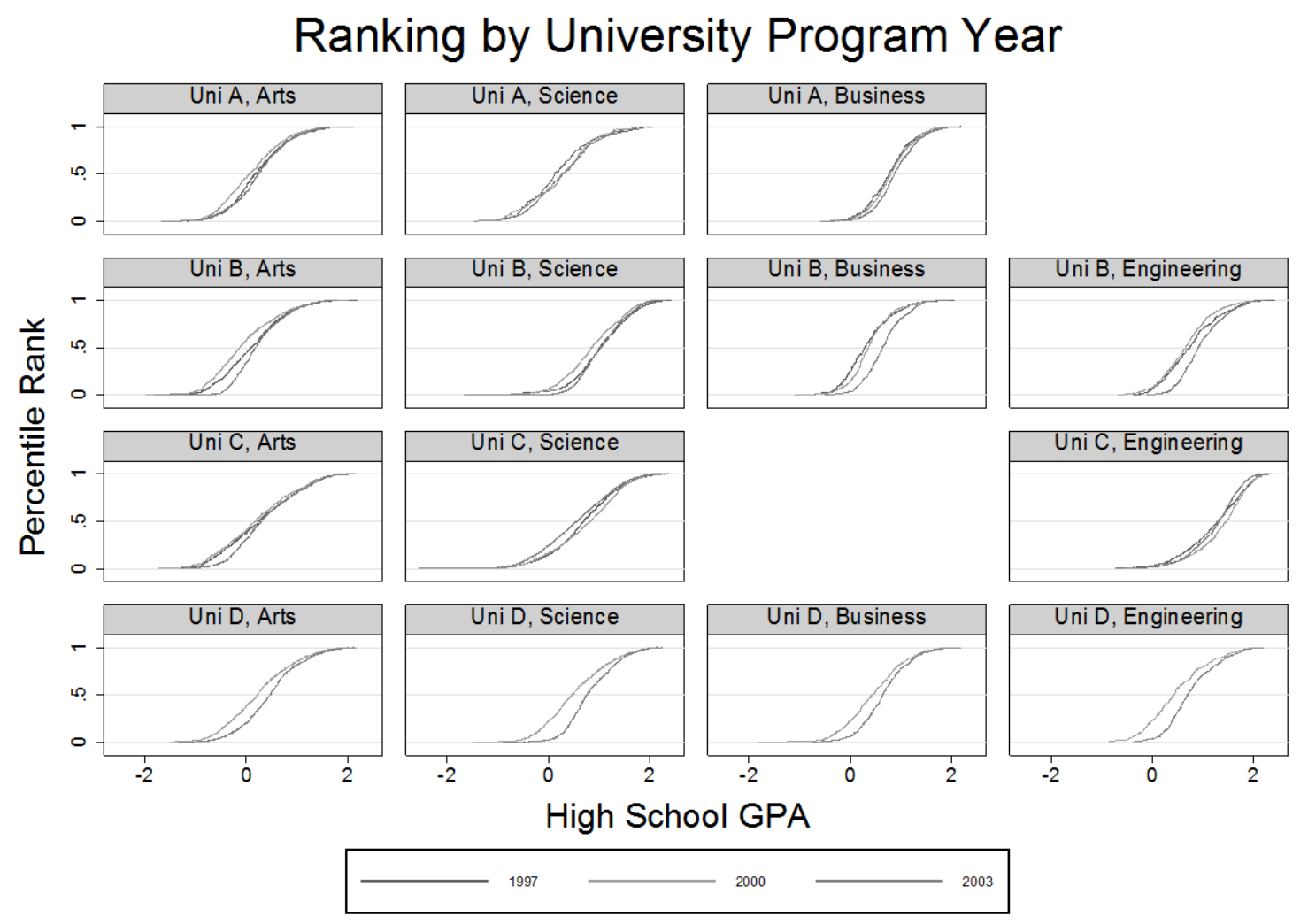

Figure 1

This article is protected by copyright. All rights reserved. 


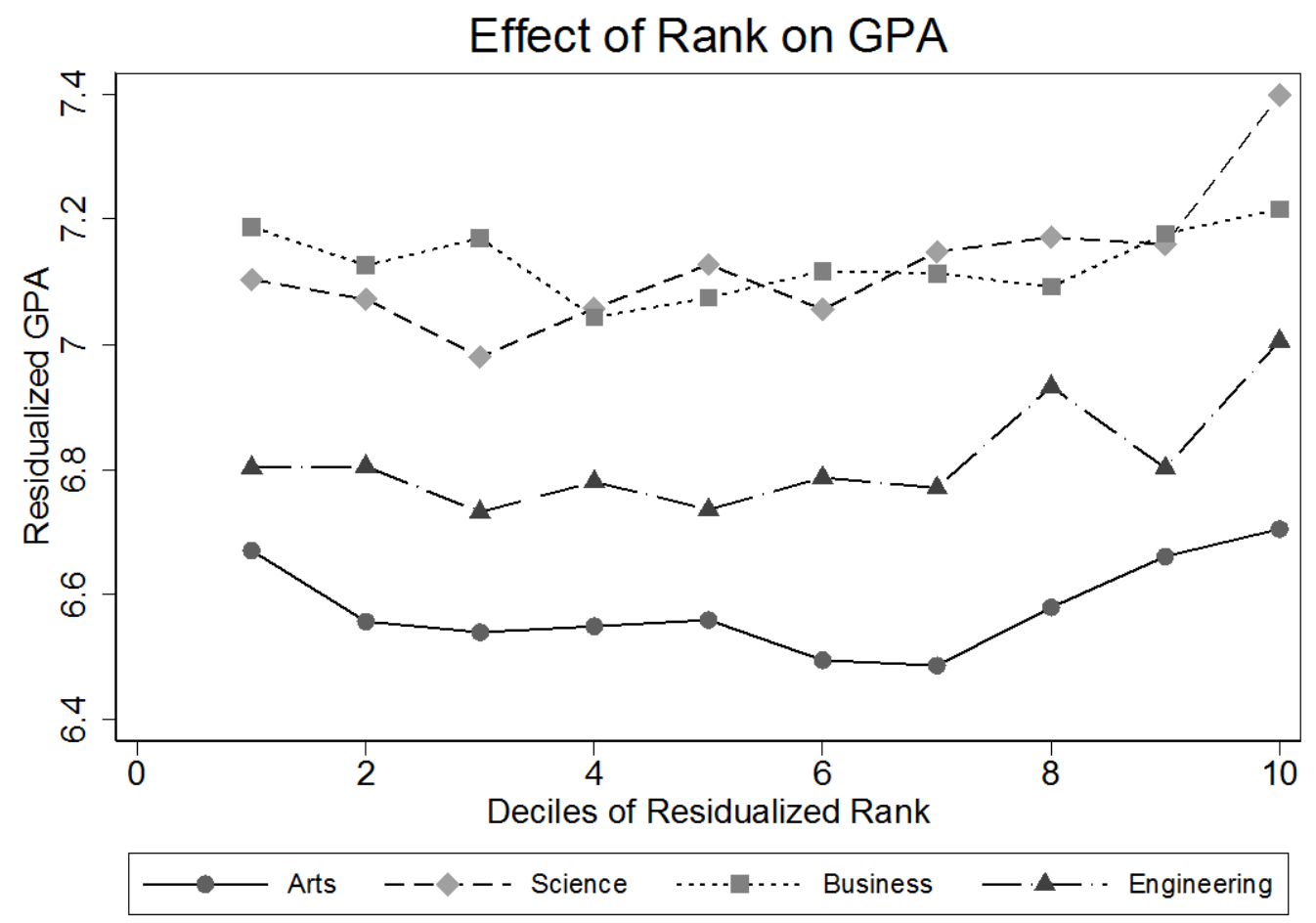

Figure 2

This article is protected by copyright. All rights reserved. 


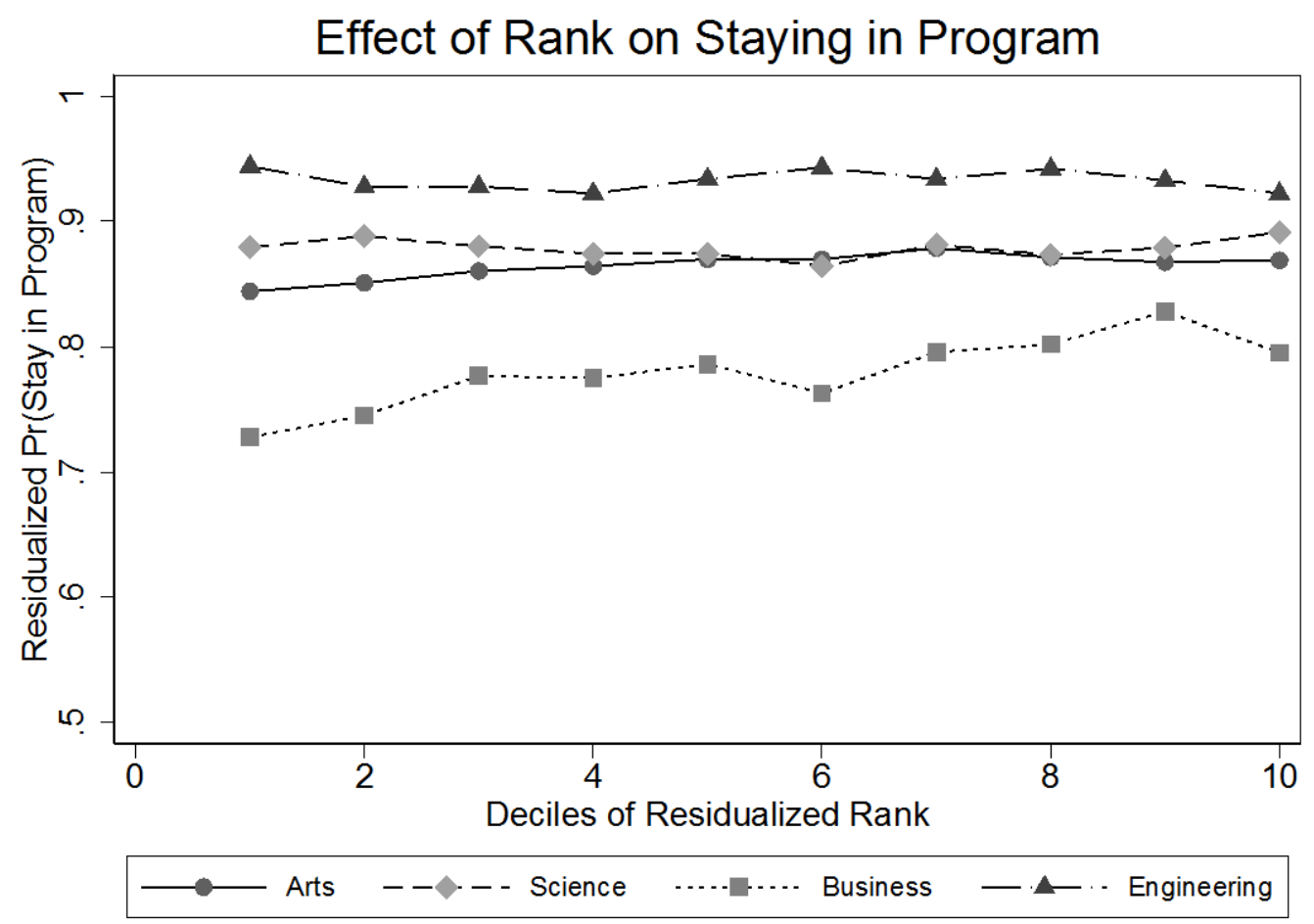

Figure 3

This article is protected by copyright. All rights reserved. 


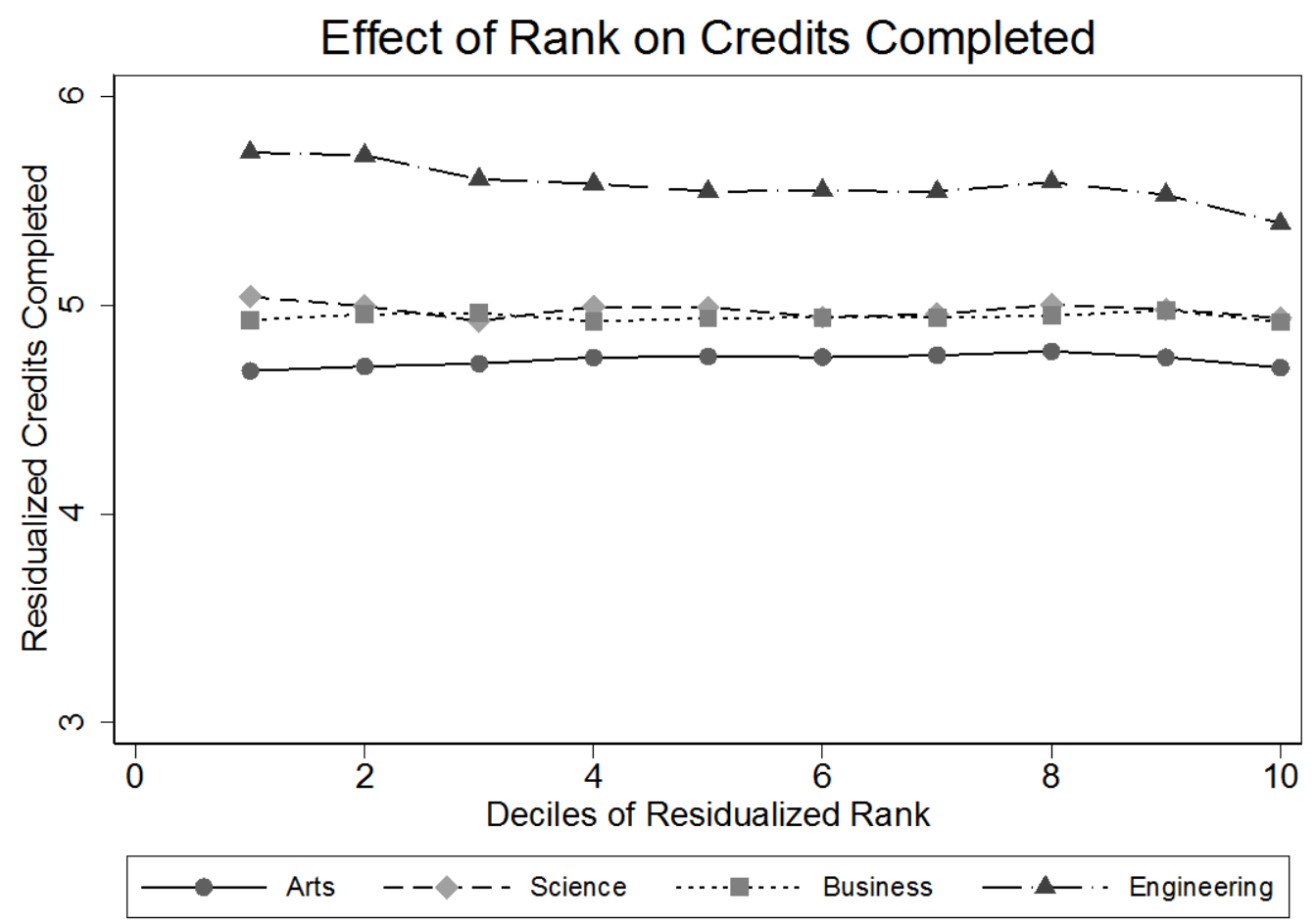

Figure 4

This article is protected by copyright. All rights reserved. 


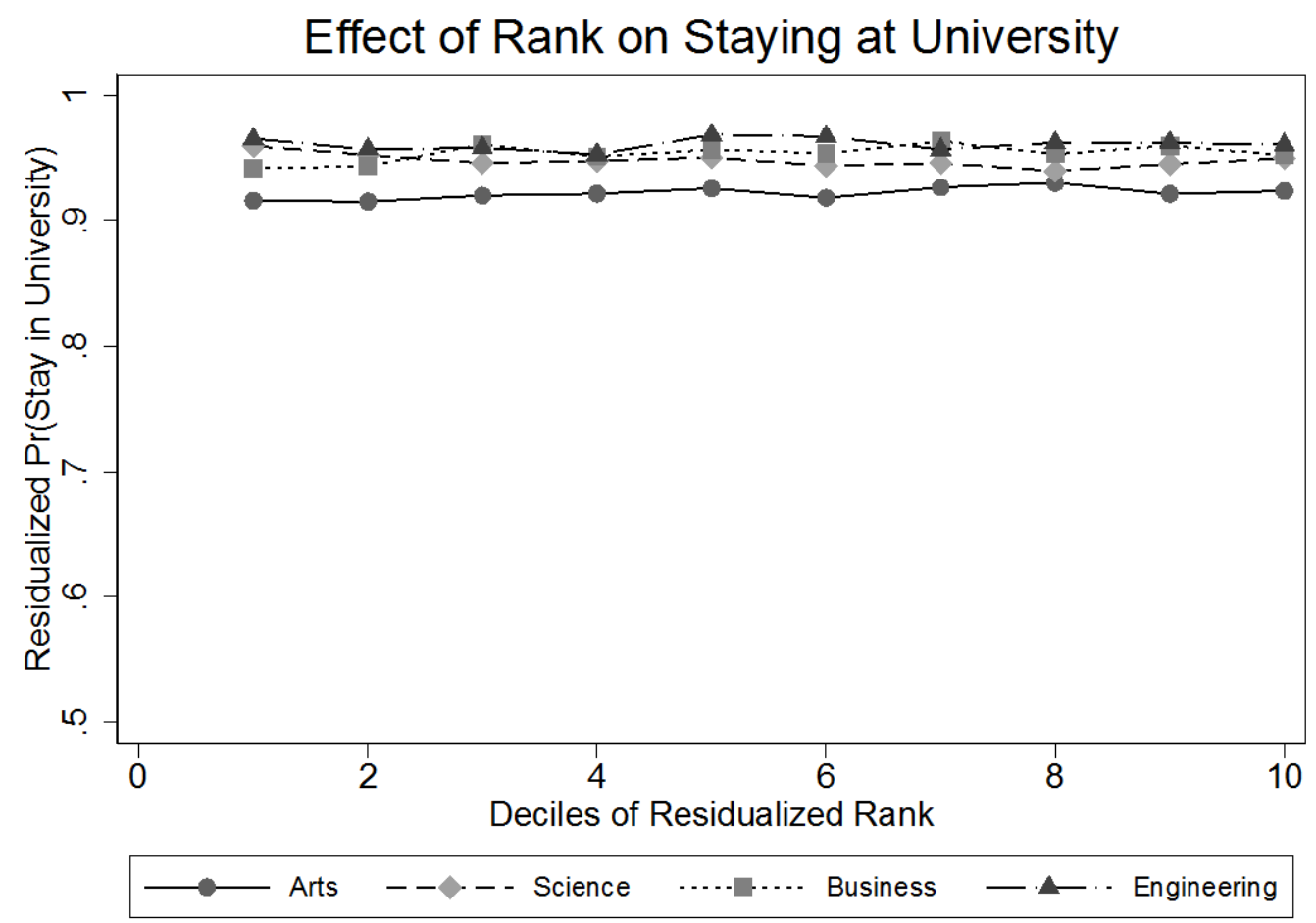

Figure 5

This article is protected by copyright. All rights reserved. 


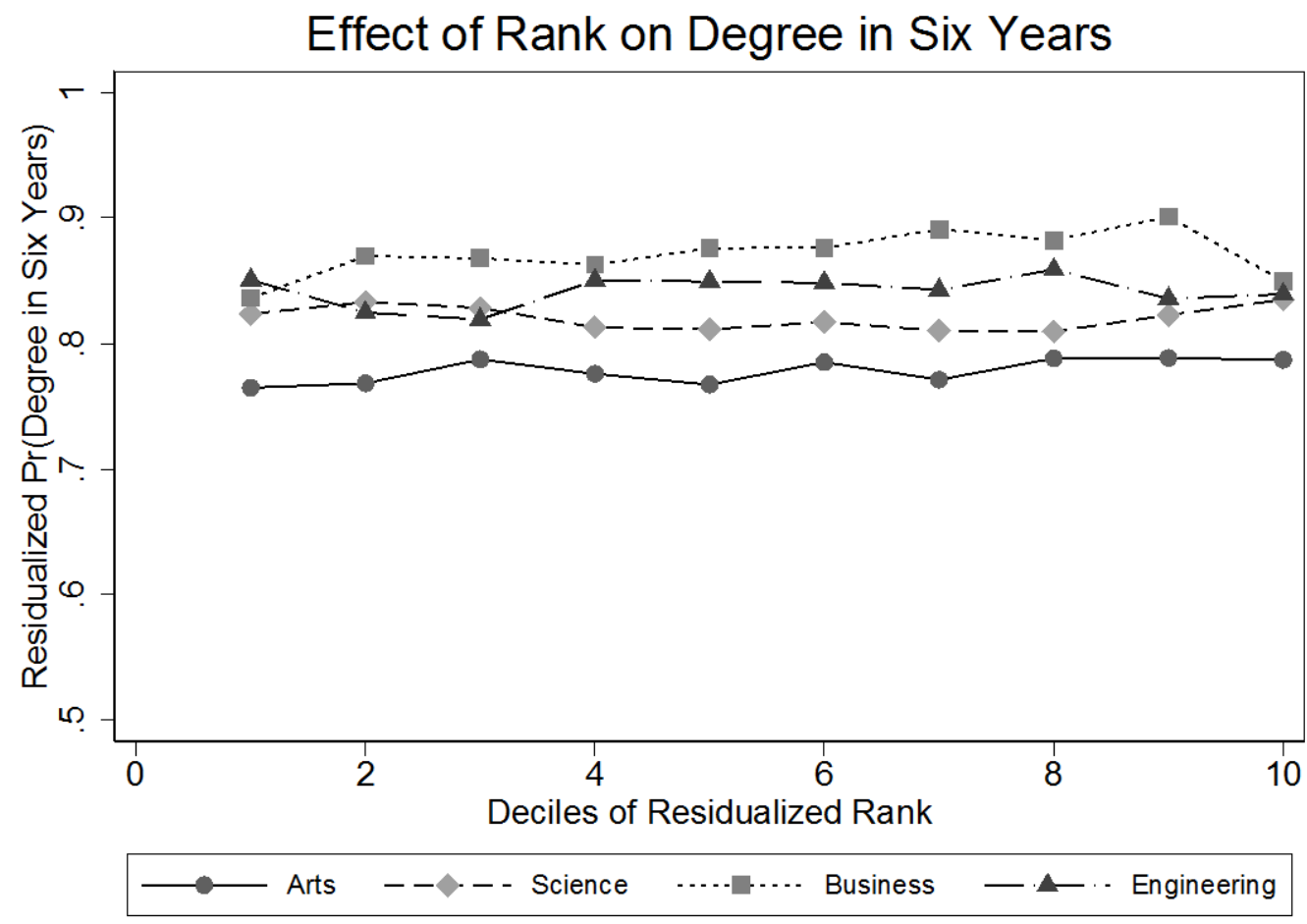

Figure 6

This article is protected by copyright. All rights reserved. 
Figure 7

This article is protected by copyright. All rights reserved. 
Figure 8

This article is protected by copyright. All rights reserved. 
Figure 9

This article is protected by copyright. All rights reserved. 


\title{
Appendix 1 - Supplemental Tables and Figures
}

Table A1: Sample Means for Control Measures in Analysis

\section{Panel A: High School GPA}

\author{
HS GPA
}

\section{Panel B: Characteristics Derived from Application Data}

Student is Registered in her Top Choice for Program \& University

Distance from Home to University

Female Student

Student is a Permanent Resident

Students Home Language is English

Share of Students Attending the High School that Enroll in University

Share of Applicants from the High School that are Female

Attended a Catholic High School

Average Number of Students in the Cohort Enrolled in the

University/Program

\section{Panel C: Chararacteristis of Neighbourhood From Census Data}

\section{Average Family Household Income}

$\%$ of Families with Lone Mothers

$\%$ of Adults with a Bachelor Degree or Higher

$\%$ of individuals aged 15 or older that are unemployed

$\%$ of the population that are not a visible miniority

$\%$ of Population Aged 15-24

$\%$ of Population Aged 25-34

$\%$ of Population Aged 35-44

$\%$ of Population Aged 45-54

\begin{tabular}{|c|c|c|c|c|c|c|c|c|c|c|c|c|c|c|}
\hline \multirow[t]{2}{*}{$\begin{array}{c}\text { Overal } \\
1\end{array}$} & \multicolumn{4}{|c|}{ Arts } & \multicolumn{4}{|c|}{ Science } & \multicolumn{3}{|c|}{ Business } & \multicolumn{3}{|c|}{ Engineering } \\
\hline & A & B & C & D & A & B & C & D & A & B & D & B & C & D \\
\hline 0.58 & 0.14 & 0.19 & 0.31 & 0.38 & 0.32 & 0.99 & 0.71 & 0.71 & 0.79 & 0.45 & 0.56 & 0.80 & 1.29 & 0.61 \\
\hline 0.61 & 0.51 & 0.55 & 0.59 & 0.69 & 0.42 & 0.62 & 0.72 & 0.59 & 0.56 & 0.49 & 0.58 & 0.40 & 0.82 & 0.47 \\
\hline 113 & 104 & 65 & 92 & 127 & 116 & 92 & 126 & 165 & 110 & 75 & 172 & 86 & 134 & 140 \\
\hline 0.56 & 0.71 & 0.71 & 0.71 & 0.66 & 0.56 & 0.68 & 0.46 & 0.62 & 0.46 & 0.47 & 0.43 & 0.19 & 0.21 & 0.17 \\
\hline 0.06 & 0.01 & 0.04 & 0.04 & 0.02 & 0.02 & 0.07 & 0.08 & 0.03 & 0.04 & 0.09 & 0.10 & 0.15 & 0.10 & 0.09 \\
\hline 0.87 & 0.96 & 0.91 & 0.88 & 0.94 & 0.95 & 0.85 & 0.80 & 0.90 & 0.89 & 0.83 & 0.83 & 0.75 & 0.74 & 0.85 \\
\hline 0.18 & 0.12 & 0.23 & 0.20 & 0.29 & 0.12 & 0.16 & 0.14 & 0.21 & 0.10 & 0.19 & 0.20 & 0.16 & 0.13 & 0.29 \\
\hline 0.58 & 0.59 & 0.58 & 0.59 & 0.58 & 0.59 & 0.58 & 0.57 & 0.58 & 0.57 & 0.56 & 0.55 & 0.56 & 0.55 & 0.58 \\
\hline 0.25 & 0.24 & 0.31 & 0.27 & 0.27 & 0.25 & 0.26 & 0.22 & 0.26 & 0.24 & 0.26 & 0.23 & 0.23 & 0.19 & 0.21 \\
\hline \multirow[t]{2}{*}{1123} & 1187 & 1127 & 867 & 1791 & 250 & 1004 & 1747 & 1324 & 675 & 355 & 544 & 447 & 649 & 270 \\
\hline & 8078 & 7912 & 7713 & 9361 & 7729 & 8087 & 7829 & 8813 & 8559 & 8325 & 9931 & 7746 & 7987 & 8201 \\
\hline 82670 & 5 & 3 & 7 & 4 & 4 & 0 & 7 & 2 & 1 & 5 & 3 & 5 & 0 & 5 \\
\hline 0.10 & 0.10 & 0.11 & 0.10 & 0.10 & 0.10 & 0.10 & 0.10 & 0.10 & 0.09 & 0.10 & 0.10 & 0.11 & 0.10 & 0.10 \\
\hline 0.22 & 0.19 & 0.20 & 0.19 & 0.25 & 0.18 & 0.21 & 0.21 & 0.23 & 0.22 & 0.22 & 0.28 & 0.20 & 0.22 & 0.22 \\
\hline 0.07 & 0.06 & 0.07 & 0.07 & 0.06 & 0.07 & 0.07 & 0.07 & 0.06 & 0.07 & 0.07 & 0.06 & 0.07 & 0.07 & 0.07 \\
\hline 0.82 & 0.88 & 0.84 & 0.82 & 0.86 & 0.89 & 0.80 & 0.77 & 0.84 & 0.82 & 0.81 & 0.79 & 0.76 & 0.73 & 0.84 \\
\hline 0.14 & 0.14 & 0.14 & 0.14 & 0.14 & 0.14 & 0.14 & 0.14 & 0.14 & 0.14 & 0.14 & 0.15 & 0.14 & 0.14 & 0.14 \\
\hline 0.12 & 0.12 & 0.12 & 0.13 & 0.11 & 0.12 & 0.12 & 0.13 & 0.11 & 0.12 & 0.12 & 0.11 & 0.13 & 0.13 & 0.12 \\
\hline 0.16 & 0.16 & 0.16 & 0.16 & 0.16 & 0.16 & 0.16 & 0.16 & 0.16 & 0.16 & 0.16 & 0.16 & 0.16 & 0.16 & 0.16 \\
\hline 0.15 & 0.15 & 15 & 0.15 & .16 & 0.15 & 0.15 & 0.15 & 0.16 & 0.15 & 0.15 & 0.16 & 0.15 & 0.15 & 0.16 \\
\hline
\end{tabular}

This article is protected by copyright. All rights reserved. 
\% of Population Aged 55-64

$\begin{array}{lllllllllllllll}0.10 & 0.10 & 0.09 & 0.09 & 0.10 & 0.10 & 0.09 & 0.09 & 0.10 & 0.09 & 0.09 & 0.10 & 0.09 & 0.09 & 0.10\end{array}$ $\%$ of Population Aged 65p

$\begin{array}{lllllllllllllll}0.11 & 0.11 & 0.11 & 0.11 & 0.12 & 0.11 & 0.11 & 0.11 & 0.12 & 0.11 & 0.10 & 0.12 & 0.11 & 0.10 & 0.12\end{array}$

Note: High School GPA is a student's average for the top six 12th grade course used in the university admission process. The Average is normalized to have mean zero

and standard deviation one among all university applicants in each year. Panel B reports the summary statistics based on measures from the students application. Panel C reports the summary statistics based on the nearest Census years for the neighbourhood in which the student attended high school. 
Table A2: Sample Means for Subsamples Used in Analysis

\begin{tabular}{lccc}
\hline \hline & Full Sample & Subset 1 & Subset 2 \\
\cline { 2 - 4 } HS Average & 0.58 & 0.59 & 0.61 \\
Attend Top Choice & 0.61 & 0.61 & 0.63 \\
Dist from Uni & 113 & 114 & 117 \\
Female & 0.56 & 0.56 & 0.54 \\
Perm Resident & 0.06 & 0.05 & 0.05 \\
Eng Mother Tongue & 0.87 & 0.87 & 0.88 \\
Share from HS at Uni & 0.18 & 0.18 & 0.18 \\
Share Female from HS & 0.58 & 0.58 & $\mathbf{0 . 5 7}$ \\
Catholic HS & 0.25 & 0.25 & 0.24 \\
Enrolment in Uni/Prog/Yr & 1123 & 1125 & 937 \\
Avg Hhld Inc & 82670 & 82465 & $\mathbf{7 7 8 5 1}$ \\
\% Lone Mothers & 0.10 & 0.10 & $\mathbf{0 . 1 0}$ \\
\% w/ Bach Degree & 0.22 & 0.21 & $\mathbf{0 . 1 9}$ \\
\% 15p Unemp & 0.07 & 0.07 & $\mathbf{0 . 0 7}$ \\
\% Not Vis Minority & 0.82 & 0.82 & $\mathbf{0 . 8 4}$ \\
\% Age 15-24 & 0.14 & 0.14 & $\mathbf{0 . 1 3}$ \\
\% Age 25-34 & 0.12 & 0.12 & $\mathbf{0 . 1 3}$ \\
\% Age 35-44 & 0.16 & 0.16 & $\mathbf{0 . 1 6}$ \\
\% Age 45-54 & 0.15 & 0.15 & $\mathbf{0 . 1 4}$ \\
\% Age 55-64 & 0.10 & 0.09 & $\mathbf{0 . 0 9}$ \\
\% Age 65p & 0.11 & 0.11 & $\mathbf{0 . 1 0}$ \\
& & & \\
Number of Students & 114262 & 105585 & 51615 \\
\hline N
\end{tabular}

Note: The full sample is used when the outcome is university GPA or credit completion at the end of

year 1 . Subset 1 is used when the outcome is registering in the university and program in year 2 , and

Subset 3 is used when the outcome is obtaining a degree in six years. Bolded values in columns 2 and

3 indicate that the mean value is statistically different from the full sample mean at the $5 \%$ level. 
Table A3: Comparison of GPA for Different Scales

\begin{tabular}{lccc}
\hline \hline Grade & Percentage & 12-Point Scale & 4.0 Scale \\
\hline A+ & $90-100$ & 12 & 4 \\
A & $85-89$ & 11 & 3.9 \\
A- & $80-84$ & 10 & 3.7 \\
B+ & $77-79$ & 9 & 3.3 \\
B & $73-76$ & 8 & 3 \\
B- & $70-72$ & 7 & 2.7 \\
C+ & $67-69$ & 6 & 2.3 \\
C & $63-66$ & 5 & 2 \\
C- & $60-62$ & 4 & 1.7 \\
D+ & $57-59$ & 3 & 1.3 \\
D & $53-56$ & 2 & 1 \\
D- & $50-52$ & 1 & 0.7 \\
F & $0-49$ & 0 & 0 \\
\hline
\end{tabular}

This article is protected by copyright. All rights reserved. 
Our primary measure for computing a high school rank does not fully address a potential concern of variation across high schools in their grading standards. Suppose that schools $\mathrm{X}$ and $\mathrm{Y}$ have students with the same ability on average, except that school Y grades their students higher. To address this problem one could subtract a school level HS GPA mean. An issue with that approach is that if both schools have the same grading standards, but students at school Y have higher ability on average than students at school X, then taking deviations from high school means would treat students of equal distance from the school mean as equivalent in terms of ability, when in fact they are not. The results below, however, report our key estimates if we adopt this alternative approach for computing student rank. 
Table A4: Main Results using Ranking based on Alternative Standardization of HS GPA

\begin{tabular}{|c|c|c|c|c|c|c|c|c|c|c|}
\hline & \multicolumn{2}{|c|}{$\begin{array}{l}\text { University GPA } \\
\text { in Year } 1\end{array}$} & \multicolumn{2}{|c|}{$\begin{array}{l}\text { Credit } \\
\text { Completions in } \\
\text { Year } 1\end{array}$} & \multicolumn{2}{|c|}{$\begin{array}{l}\text { Observed } \\
\text { Registering in } \\
\text { Year } 2 \text { at the } \\
\text { University }\end{array}$} & \multicolumn{2}{|c|}{$\begin{array}{c}\text { Observed } \\
\text { Remaining in the } \\
\text { same Program of } \\
\text { Study at the } \\
\text { University in } \\
\text { Year } 2\end{array}$} & \multicolumn{2}{|c|}{$\begin{array}{c}\text { Observed } \\
\text { Receiving a } \\
\text { Degree within } 6 \\
\text { years }\end{array}$} \\
\hline & (1) & $(2)$ & (3) & (4) & (5) & (6) & $(7)$ & (8) & (9) & (10) \\
\hline Rank & $\begin{array}{c}\mathbf{0 . 1 0 4} \\
(0.008)\end{array}$ & $\begin{array}{c}\mathbf{0 . 0 9 1} \\
(0.010)\end{array}$ & $\begin{array}{c}\mathbf{0 . 0 2 2} \\
(0.009)\end{array}$ & $\begin{array}{c}\mathbf{0 . 0 1 6} \\
(0.008)\end{array}$ & $\begin{array}{c}\mathbf{0 . 0 0 4} \\
(0.001)\end{array}$ & $\begin{array}{c}\mathbf{0 . 0 0 5} \\
(0.001)\end{array}$ & $\begin{array}{c}\mathbf{0 . 0 2 0} \\
(0.006)\end{array}$ & $\begin{array}{c}\mathbf{0 . 0 2 2} \\
(0.007)\end{array}$ & $\begin{array}{c}\mathbf{0 . 0 0 8} \\
(0.003)\end{array}$ & $\begin{array}{r}\mathbf{0 . 0 0 8} \\
(0.003)\end{array}$ \\
\hline $\begin{array}{l}\text { HS GPA Dummies } \\
\text { UniversityXProgram }\end{array}$ & Yes & Yes & Yes & Yes & Yes & Yes & Yes & Yes & Yes & Yes \\
\hline $\begin{array}{l}\text { Fixed Effects } \\
\text { UniversityXProgramXYear }\end{array}$ & Yes & No & Yes & No & Yes & No & Yes & No & Yes & No \\
\hline $\begin{array}{l}\text { Effects } \\
\text { Year Effects }\end{array}$ & No & Yes & No & Yes & No & Yes & No & Yes & No & Yes \\
\hline $\begin{array}{l}\text { Student, Neighbourhood, } \\
\text { Schooling Controls }\end{array}$ & Yes & Yes & Yes & Yes & Yes & Yes & Yes & Yes & Yes & Yes \\
\hline $\begin{array}{l}\text { Number of Students } \\
\text { R-Square }\end{array}$ & $\begin{array}{c}114262 \\
0.42 \\
\end{array}$ & $\begin{array}{c}114262 \\
0.42 \\
\end{array}$ & $\begin{array}{c}114262 \\
0.20 \\
\end{array}$ & $\begin{array}{c}114262 \\
0.21 \\
\end{array}$ & $\begin{array}{c}105585 \\
0.04\end{array}$ & $\begin{array}{c}105585 \\
0.04 \\
\end{array}$ & $\begin{array}{c}105585 \\
0.08 \\
\end{array}$ & $\begin{array}{c}105585 \\
0.08 \\
\end{array}$ & $\begin{array}{c}51615 \\
0.09 \\
\end{array}$ & $\begin{array}{c}51615 \\
0.09 \\
\end{array}$ \\
\hline
\end{tabular}


Note: Rank coefficient is scaled to represent effect of increasing rank by one decile. Standard Errors are clustered at the

universityXprogram level. Student, neighbourhood, schooling controls include all measures listed in Appendix Table 1, plus high school

fixed effects and universityXprogram averages of all individual controls. The HS GPA underlying the ranking in these regressions has been

standardized by removing year means and high school means, and dividing by the year standard deviation. Coefficients in bold are

significant at $\mathrm{p}<0.05$. Coefficients in bold italics are significant at $\mathrm{p}<0.10$.

Table A5: Predicting Outcomes with High School GPA

\begin{tabular}{|c|c|c|c|c|c|c|c|c|c|c|}
\hline & \multicolumn{2}{|c|}{$\begin{array}{c}\text { University GPA } \\
\text { in Year } 1\end{array}$} & \multicolumn{2}{|c|}{$\begin{array}{c}\text { Credit } \\
\text { Completions in } \\
\text { Year } 1\end{array}$} & \multicolumn{2}{|c|}{$\begin{array}{l}\text { Observed } \\
\text { Registering in } \\
\text { Year } 2 \text { at the } \\
\text { University }\end{array}$} & \multicolumn{2}{|c|}{$\begin{array}{c}\text { Observed } \\
\text { Remaining in the } \\
\text { same Program of } \\
\text { Study at the } \\
\text { University in } \\
\text { Year } 2 \\
\end{array}$} & \multicolumn{2}{|c|}{$\begin{array}{c}\text { Observed } \\
\text { Receiving a } \\
\text { Degree within } 6 \\
\text { years }\end{array}$} \\
\hline & $(1)$ & (2) & (3) & (4) & (5) & (6) & (7) & (8) & (9) & $(10)$ \\
\hline HS GPA & $\begin{array}{c}2.147 \\
(0.009)\end{array}$ & $\begin{array}{c}2.215 \\
(0.009)\end{array}$ & $\begin{array}{c}\mathbf{0 . 4 0 9} \\
(0.004)\end{array}$ & $\begin{array}{c}\mathbf{0 . 4 1 9} \\
(0.004)\end{array}$ & $\begin{array}{c}\mathbf{0 . 0 4 6} \\
(0.001)\end{array}$ & $\begin{array}{c}\mathbf{0 . 0 4 9} \\
(0.001)\end{array}$ & $\begin{array}{c}\mathbf{0 . 0 8 0} \\
(0.002)\end{array}$ & $\begin{array}{c}\mathbf{0 . 0 8 4} \\
(0.002)\end{array}$ & $\begin{array}{c}\mathbf{0 . 1 2 3} \\
(0.003)\end{array}$ & $\begin{array}{r}\mathbf{0 . 1 2 9} \\
(0.003)\end{array}$ \\
\hline High School Fixed Effects & No & Yes & No & Yes & No & Yes & No & Yes & No & Yes \\
\hline Number of Students & 114262 & 114262 & 114262 & 114262 & 105585 & 105585 & 105585 & 105585 & 51615 & 51615 \\
\hline R-Square & 0.32 & 0.38 & 0.09 & 0.12 & 0.02 & 0.04 & 0.03 & 0.05 & 0.05 & 0.07 \\
\hline
\end{tabular}

This article is protected by copyright. All rights reserved. 
Note: Coefficients in bold italics are significant at $\mathrm{p}<0.10$. Standard Errors are robust to heteroskedasticity. No other controls are included in these regressions. Coefficients in bold are significant at $\mathrm{p}<0.05$.

This article is protected by copyright. All rights reserved. 
Table A6: Correlations Between Cohort/Program/University Rank and Single Course Rank Measures

Correlation with Registrant Rank in Univ/Prog/Cohort

Course Rank for Registrants in Univ/Prog/Cohort HS English

HS Calculus

\begin{tabular}{cccc} 
Arts & Science & Business & Engineering \\
\hline 0.66 & 0.57 & 0.50 & 0.49
\end{tabular}

HS Data Management

0.69

0.48

0.68

HS Chemistry

0.71

0.54

0.68

HS Physics

0.68

0.67

HS Biology

0.68

0.69

Note: Each cell represents the correlation between the HS GPA rank and the individual course rank

within the same university/program/cohort. Missing cells for some programs reflect the fact that too few students took those courses to allow us to rank them on that basis. 
Figure A1 - The Effect of Rank on University Persistence Conditional on Registering in Year 2

This article is protected by copyright. All rights reserved. 
Figure A2 - The Effect of Rank on Graduation in Six Years Conditional on Registering in Year 2

This article is protected by copyright. All rights reserved. 


\section{Appendix 2 - Variation in Rank Across Schools}

As noted in the Empirical Strategy section, for our main results we use variation in rank across time but within a program at a university to identify the rank effect, holding entry age constant. Changes in rank for equally able students are driven by the random year-to-year differences in the average ability of the entry cohort. Like in the class size and peer effects studies by Hoxby (2000a,b), this may come from idiosyncratic variation across in the underlying population across entry cohorts. Alternatively, we could have used variation within a program and year, but across universities to measure the rank effect. We decided against that strategy because variation in rank across universities might be correlated with characteristics of the schools, like the quality of the professors for example. Nevertheless, looking the effect of rank using differences across schools corresponds more closely with how people think about the BFLPE: is an identical student better off ranked highest at University A Arts, or lowest at University B Arts? Because of its intuitive appeal, in Table B1 we estimate the rank effect using variation across universities, with a specification that controls for program by year effects, and a standalone university effect to absorb fixed differences across programs and time.

The results in Table B1 show some differences relative to the main results from Tables 3 and 4 . The magnitude of the GPA effect is about $10 \%$ higher, and the effect of staying in program disappears. Other results remain insignificant. One could conclude that there are unobserved differences across universities (that are not controlled by a university fixed effect) that confound the relationship between rank and the outcomes, which we control for in our main results in Tables 3 and 4. 
Table B1: Rank Effects using Across School Variation

Univ/Prog/Cohort Rank

\section{HS GPA Dummies}

ProgramXYear Fixed Effects

University Fixed Effects

Student, Neighbourhood, Schooling Controls

Number of Students

R-Square

Note: Rank

Standard Errors are clustered at the universityXprogram level. Student, neighbourhood, schooling controls include all measures listed in

Appendix Table 1, plus high school fixed effects and universityXprogram averages of all individual controls. Coefficients in bold are significant at $\mathrm{p}<0.05$.

\begin{tabular}{ccccc}
$\begin{array}{c}\text { University } \\
\text { GPA in } \\
\text { Year } 1\end{array}$ & $\begin{array}{c}\text { Credit } \\
\text { Completions } \\
\text { in Year 1 }\end{array}$ & $\begin{array}{c}\text { Observed } \\
\text { Registering in } \\
\text { Year 2 at the } \\
\text { University }\end{array}$ & $\begin{array}{c}\text { Observed } \\
\text { Remaining in the } \\
\text { same Program of } \\
\text { Study at the } \\
\text { University in } \\
\text { Year } 2\end{array}$ & $\begin{array}{c}\text { Observed } \\
\text { Receiving a } \\
\text { Degree } \\
\text { within } 6 \\
\text { years }\end{array}$ \\
\hline$(1)$ & $(2)$ & $(3)$ & $(4)$ & $(5)$ \\
\hline $\mathbf{0 . 0 9 7}$ & 0.002 & $\mathbf{0 . 0 0 4}$ & $\mathbf{0 . 0 1 6}$ & $\mathbf{0 . 0 0 8}$ \\
$(0.008)$ & $(0.009)$ & $(0.001)$ & $(0.006)$ & $(0.003)$ \\
Yes & Yes & Yes & Yes & Yes \\
Yes & Yes & Yes & Yes & Yes \\
Yes & Yes & Yes & Yes & Yes \\
Yes & Yes & Yes & Yes & Yes \\
114262 & 114262 & 105585 & 105585 & 51615 \\
0.42 & 0.20 & 0.04 & 0.08 & 0.09 \\
\hline
\end{tabular}

$<0.10$. 
This article is protected by copyright. All rights reserved. 


\section{University Library}

\section{- M M I N E R VA A gateway to Melbourne's research publications}

Minerva Access is the Institutional Repository of The University of Melbourne

Author/s:

Payne, AA;Smith, J

Title:

Big Fish, Small Pond: The Effect of Rank at Entry on Postsecondary Outcomes

Date:

2020-01-20

Citation:

Payne, A. A. \& Smith, J. (2020). Big Fish, Small Pond: The Effect of Rank at Entry on Postsecondary Outcomes. Southern Economic Journal, 86 (4), pp.1475-1509. https:// doi.org/10.1002/soej.12420.

Persistent Link:

http://hdl.handle.net/11343/276835 